\title{
Republic of Estonia: Financial System Stability Assessment
}

This Financial System Stability Assessment on the Republic of Estonia was prepared by a staff team of the International Monetary Fund as background documentation for the periodic consultation with the member country. It is based on the information available at the time it was completed on February 13, 2009. The views expressed in this document are those of the staff team and do not necessarily reflect the views of the government of the Republic of Estonia or the Executive Board of the IMF.

The policy of publication of staff reports and other documents by the IMF allows for the deletion of market-sensitive information.

Copies of this report are available to the public from

International Monetary Fund • Publication Services

700 19th Street, N.W. • Washington, D.C. 20431

Telephone: (202) 6237430 • Telefax: (202) 6237201

E-mail: publications@imf.org • Internet: http://www.imf.org

\section{International Monetary Fund \\ Washington, D.C.}



INTERNATIONAL MONETARY FUND

REPUBLIC OF ESTONIA

Financial System Stability Assessment

Prepared by the Monetary and Capital Markets and European Departments

Approved by Christopher Towe and Marek Belka

February 13, 2009

- This report presents the conclusions of the Financial Sector Assessment Program (FSAP) Update mission that visited Estonia from February 18-27, 2008. The findings and recommendations were discussed with the authorities during the Article IV Consultation mission in May 2008. The report has been updated to reflect the findings of a staff visit in December 2008.

- The FSAP Update team comprised Steven Seelig (Mission Chief, MCM), Nada Choueiri (EUR), Elina Ribakova (MCM), Joon Soo Lee and Heinz Rudolph (both World Bank), and Goran Lind (Sveriges Riksbank). Magally Bernal (MCM) assisted the mission. The mission received excellent cooperation and support from the authorities.

- The main findings of the FSAP Update are:

- The Estonian banking sector has significant vulnerabilities from its real estate lending. Much of the recent loan growth to this sector has been funded in euros, at floating rates, and used to fund long-term euro-denominated mortgages, implying both liquidity and credit risk exposure.

- The rapid expansion of the banking sector has been funded, to a large extent, by short-term foreign borrowing from parent banks, making Estonia vulnerable to a disruption in international financial markets. Estonian subsidiary banks have a maturity mismatch that makes them vulnerable to a liquidity shock.

- There is a need for Estonia to more fully develop its financial safety net, including implementing a lender-of-last-resort (LOLR) capability and an expanded bank resolution framework. Consideration needs to be given to increasing the target size of the deposit guarantee fund.

- The creation of the EFSA has improved supervision in Estonia and its organizational structure has been designed in a manner to address the unique features of the Estonian financial sector. There are no serious weaknesses in bank supervision and regulation.

- Although the global financial crisis has placed the Estonian system under pressure, thus far it has remained resilient.

- The main author of this report is Steven A. Seelig.

- FSAP assessments are designed to assess the stability of the financial system as a whole and not that of individual institutions. They have been developed to help countries identify and remedy weaknesses in their financial sector structure, thereby enhancing their resilience to macroeconomic shocks and cross-border contagion. Assessments do not cover risks that are specific to individual institutions such as asset quality, operational or legal risks, or fraud. 


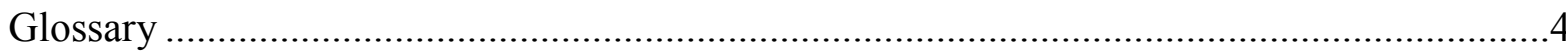

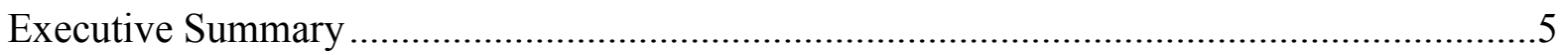

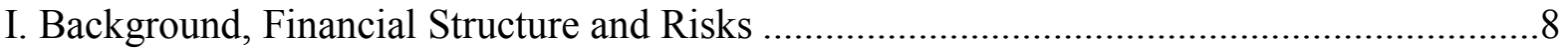

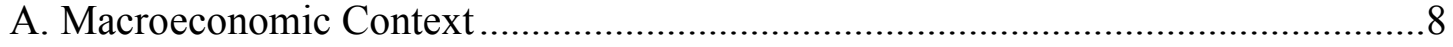

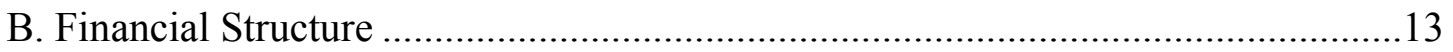

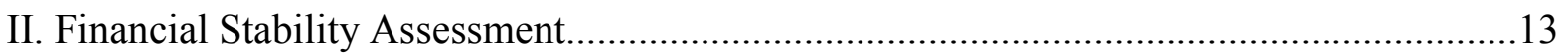

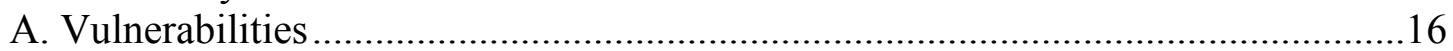

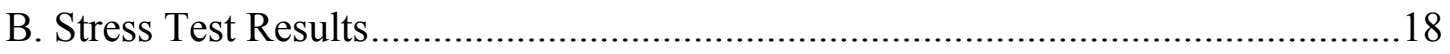

III. Risk Mitigation: Financial Safety Net and Crisis Management …………………...........24

A. Emergency Liquidity Assistance …………………………………………....24

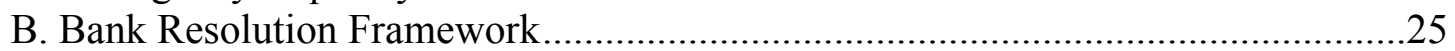

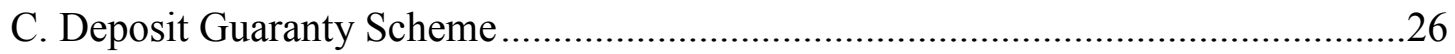

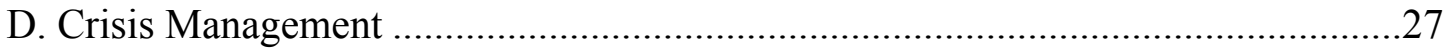

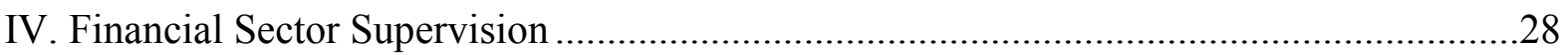

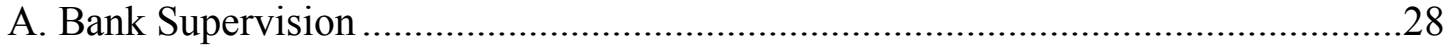

B. Supervision of Private Pension Funds.......................................................................30

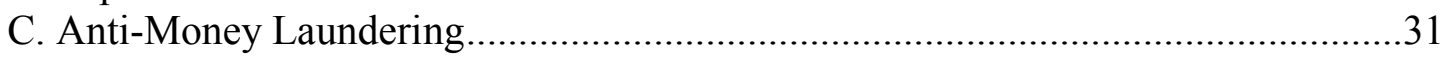

Tables

1. Sectoral Balance Sheet Exposures, December 2007.......................................................12

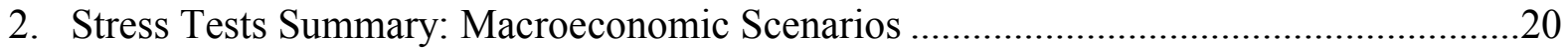

3. Stress Tests Summary: Additional Economic Downturn Scenarios 1 ...............................22

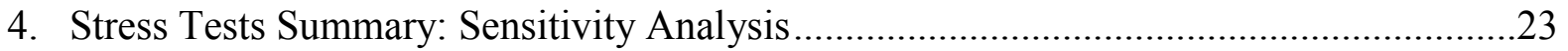

Figures

1. Current Account Developments, 2001-08

2. Average Apartment Price, 2000Q1-2008Q1 ………................................................... 10

3. Number of Apartment Transactions and Median Price, Jan 2004-Nov 2008 ...................10

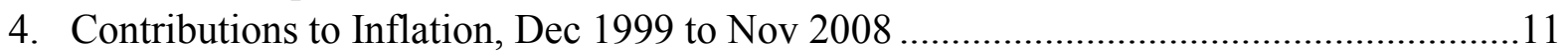

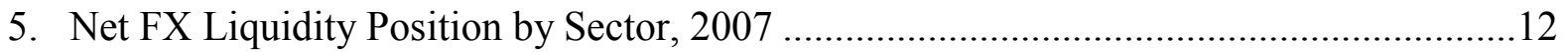

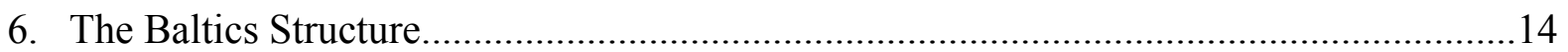

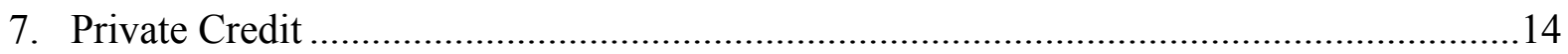

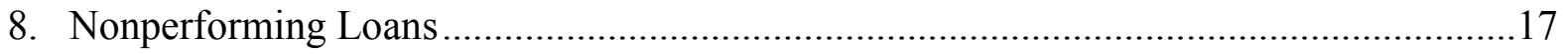

Boxes

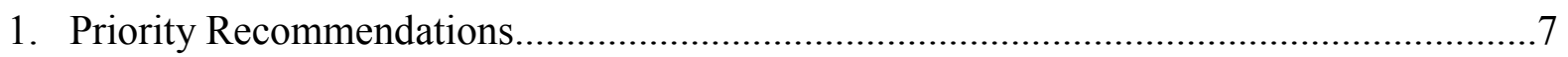

2. Description of the Stress Test Methodology..............................................................19 
Appendices

1. Update on 2000 FSAP Recommendations. .32

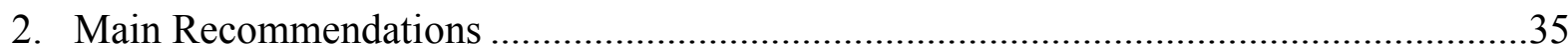

3: Intersectoral Asset and Liability Positions, December 2007 ……....................................37

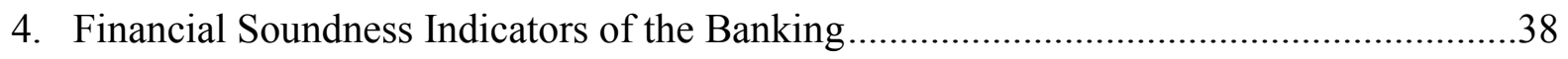

5. Selected European Countries: Capital, NPL, and Profitability............................................39

6. Macroeconomic Stress Test Scenarios: Summary of Key Parameters ...............................40 


\section{GLOSSARY}

AMA

BCP

BoE

CAR

CBA

CEBS

CIA

CRD

DGF

ECB

EFSA

ELA

EU

FSA

FSAP

FX

GDP

ICAAP

IFRS

IOSCO

IRB

LGD

LOLR

LSR

LTV

$\mathrm{MoF}$

$\mathrm{MoU}$

NPLS

ROAA

ROAE

ROSC

SEB

SRO

UCITS

VaR
Advanced Measurement Approach

Basel Core Principles for Effective Banking Supervision

Bank of Estonia (Eesti Pank)

Capital Adequacy ratio

Currency Board Arrangement

Committee of European Banking Supervisors

Credit Institutions Act

Capital Requirements Directive

Deposit Guaranty Fund

European Central Bank

Estonian Financial Supervision Authority

Emergency Liquidity Assistance

European Union

Financial Supervision Authority

Financial Sector Assessment Program

Foreign Exchange

Gross Domestic Product

Internal Capital Adequacy Assessment Process

International Financial Reporting Standards

International Organization of Securities Commissions

Internal Ratings-Based (Approach)

Loss-Given-Default

Lender of Last Resort

Loan Service Ratio

Loan to Value (Ratio)

Ministry of Finance

Memorandum of Understanding

Nonperforming Loans

Return on Average Assets

Return on Average Equity

Report on Standards and Codes

Skandinaviska Enskilda Banken

Self-Regulatory Organization

Units in Collective Investments in Transferable Securities

Value at Risk 


\section{EXECUTIVE SUMMARY}

The Estonian authorities have made significant progress since the 2000 FSAP in improving financial sector supervision (see Appendix I). The creation of the Estonian Financial System Authority (EFSA) has improved supervision in Estonia. Its organizational structure has been designed in a manner to effectively address the unique features of the Estonian financial sector.

The Estonian financial sector is highly concentrated and foreign owned. Two Swedishowned banks control 68 percent of banking assets and two other Nordic-owned banks control an additional 26 percent. These same institutions also dominate the insurance, brokerage, and investment and pension funds management sectors.

Financial indicators suggest a sound banking sector, and show particular strength in asset quality and earnings. Exceptional economic growth, in recent years, has been fueled by bank lending and has brought strong profitability and asset growth to Estonian banks. Moreover, Estonian banks have proven resilient in the face of recent problems in Latvia. Although banks have increased provisions as nonperforming loans (NPLs) have risen, an increase in lending rates and spreads have offset the impact on earnings.

However, while the current economic slowdown has not yet led to weaker banking sector performance, there are signs that credit quality is deteriorating. Banks are heavily concentrated in real estate loans, and the market has weakened and prices are falling. Housing loans 60 days past-due have almost doubled during the past six months, albeit from low levels.

The rapid expansion of bank mortgage lending has been funded by shorter-term foreign borrowing, leaving Estonia vulnerable to a shock to the real estate sector or a disruption in international financial markets. Loan growth to this sector was funded in euros, at floating rates, from parent banks and used to fund long-term euro-denominated floating rate mortgages. Estonian banks have a maturity mismatch that makes them vulnerable to a liquidity shock. Moreover, given that banks' short-term liquidity exposure in foreign currencies significantly exceeds Estonia's international reserves, this constitutes foreign exchange vulnerability as well. The vulnerability of the banking sector to a liquidity shock was confirmed by a run on one of the large banks in late September. Liquidity problems were avoided by policy actions of the home-country central bank that allowed the parent to provide sufficient liquidity to its Baltic subsidiaries.

Estonia operates under a currency board that presently limits its ability to provide liquidity support to banks. However, its relatively high reserve requirements provide a partial buffer. Recently, moreover, the BoE has developed procedures for meeting the 
funding needs of banks, but these would apply only to small banks and the conditions and policies surrounding their use will only be decided on a case-by-case basis should there be a need. Recognizing the need to be able to provide liquidity to the large banks, the authorities have developed a plan to provide ELA to the large foreign-owned banks with the support of a neighboring central bank. This will be essential for the system no to be severely compromised in the event of a liquidity crisis.

There remains a need for Estonia to more fully develop its safety net, including an expanded bank resolution framework. The authorities have begun to explore options to address these vulnerabilities, while at the same time preserving the integrity of their currency board arrangement. With a more robust resolution framework, the deposit guarantee fund would be able to provide effective limited coverage of the entire system if the target amount of the fund were doubled to 4 percent of guaranteed deposits.

The bank supervisory framework in Estonia is in line with international standards and practices and EFSA provides Estonia with a strong prudential supervisory body. Most of the weaknesses identified in the 2000 Basel Core Principles Assessment have been addressed and the capital adequacy regime in Estonia is in line with international standards and consistent with the European Union (EU) Capital Requirements Directive. In response to a recommendation of the FSAP-Update mission the supervisory board of the EFSA increased staffing to meet the increasing demands of Basel II and Solvency 2. Other recommendations of the mission have also been implemented by the EFSA.

The regulatory framework for pension fund oversight should be strengthened. The supervisory framework should move from a compliance-based approach to one focused on risks, including the adequacy of reserves during the payout period. The EFSA should prohibit the practice of requiring a saver to purchase other products from the same firm and consider other measures that would result in cost reductions. In response to the mission's recommendation, the authorities liberalized the investment limit on the maximum equity exposure allowed for pension funds. 


\section{Box 1. Estonia: Priority Recommendations ${ }^{1}$}

\section{Financial Safety Net}

- Formulate a policy for emergency liquidity assistance (ELA), including the basis for taking a decision to grant ELA and complete the plans for large bank ELA. Finalize procedures for the collateral required, the terms for lending, and documentation.

- Assess policies and measures across governmental bodies for crisis management, including a scenario in which Estonian banks are unable to obtain liquidity from their parents.

- Conduct a crisis simulation exercise with other Baltic authorities responsible for subsidiaries of Estonian banks and the Swedish authorities responsible for the parent banks.

- Adopt legislation that introduces a special resolution framework for banks that allows for the quick transfer of assets and liabilities of an insolvent bank.

- Strengthen the Deposit Guarantee Fund by (i) establishing contingent liquidity arrangements to assure sufficient funding for a larger failure; (ii) increasing the target size of the fund to 4 percent of guaranteed deposits; and (iii) adopting measures to shorten the payout period from the guarantee fund.

\section{Financial Sector Supervision}

- Amend the supervisory framework for pensions to move from a compliance-based to a riskbased focus.

- Implement joint Bank of Estonia (BoE)-EFSA macrofinancial stress tests.

\section{Pensions}

- The regulation of the payout phase of the pension scheme needs to be completed and should address potential moral hazard issues.

- Require institutional separation between asset management companies and providers of depository/custodial services.

${ }^{1}$ A more detailed list of prioritized recommendations is presented in Appendix II. 


\section{BACKGROUND, FinANCIAL STRUCTURE, AND RiSKS}

\section{A. Macroeconomic Context}

1. Estonia's rapid economic growth has come with risks. Real GDP growth averaged 10 percent in 2005-2006, as rising incomes, buoyant consumer and investor expectations, and cheap global liquidity pushed domestic demand well above sustainable levels, fueling inflation and real estate prices, and tightening the labor market. Moreover, the external current account deficit widened to 18 percent of GDP by 2007 (Figure 1), and wage growth accelerated, feeding concerns about competitiveness. These imbalances, together with the delay in euro adoption ${ }^{1}$ and the deterioration in global financial markets, have raised market concern about Estonia (and the two other Baltic states), as evidenced by downgrades of its ratings outlook over the past two years ${ }^{2}$ and by the decision by the Swedish parents of the two large Estonian commercial banks to tighten lending conditions.

Figure 1. Estonia: Current Account Developments, 2001-08 (In percent of GDP)

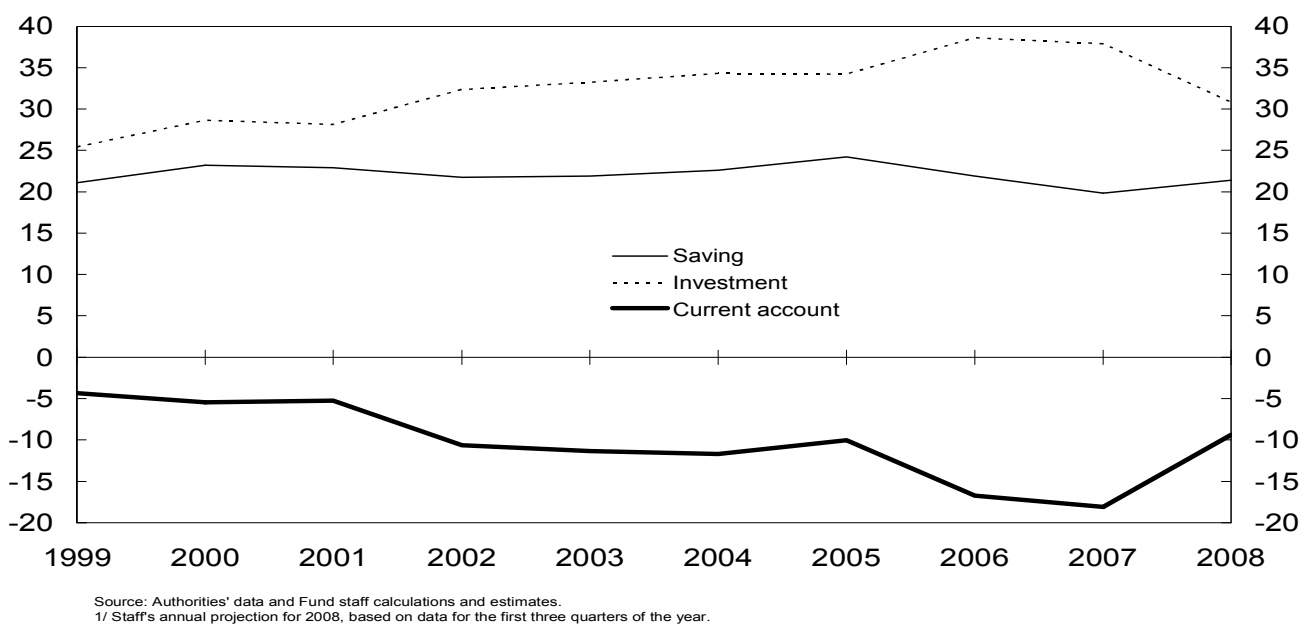

\footnotetext{
${ }^{1}$ Upon EU accession in 2004, Estonia joined ERM2 while maintaining its currency board arrangement, and targeted euro adoption in 2007. But it failed to meet the Maastricht inflation criterion in 2006-the only condition for euro adoption that Estonia does not meet. Thus, euro adoption has been delayed, and is now expected to take place in 2011 , at the earliest.

${ }^{2}$ While keeping Estonia's ratings at the same investment grade levels, Moody's and S\&P both downgraded the outlook by one notch in late 2007 from, respectively, positive to stable, and stable to negative. In January and October 2008, S\&P reaffirmed its ratings and outlook while Moody's, in October 2008, downgraded the outlook to negative but maintained its rating. Fitch lowered its outlook to negative at end-January 2008; it downgraded the rating by one notch in October 2008, maintaining the negative outlook.
} 
2. Domestic demand has now considerably weakened and the economy has been in a recession since the fourth quarter of 2007. The economy remained buoyant in the first quarter of 2007, but the turnaround in growth has been rapid since. By end-2008, with tighter credit conditions and a decline in confidence, growth in domestic demand had turned negative as both consumption and investment contracted.

3. A decline in the real estate market is also underway. Housing prices had soared at the height of the real estate market boom at the end of 2005, in the context of a tight market where apartments were often sold before construction plans were finalized. But the market, which had started easing in 2006, has seen a marked contraction over the past two years. Average prices fell by about 20 percent during 2008, after declining by nearly 10 percent in 2007 and selling periods have considerably lengthened. (Figures 2-3). The impact of these developments on household defaults have been limited through end-2008 and tightening credit standards for developers has limited risk in residential construction lending.

4. Company profits have declined in response to cost pressures. Inflation peaked at 12 percent in June 2008 (y-o-y), driven by core inflation — but also with significant contribution from food and fuel price increases (Figure 4). It subsequently dropped under 8 percent by year end, driven by both the recession at home and the drop in international oil and food prices. ${ }^{3}$ Domestic growth and new employment opportunities in the EU led to a sharp fall in the unemployment rate to $4 \frac{2}{3}$ percent in 2007 - the lowest level in Estonia's post-transition history, fueling a 14 percent rise in real wages which exacerbated the rise in unit labor costs that began in mid-2005. As a result company profits had begun to erode, albeit from high levels, and some firms have lost their international competitiveness. The recession, coupled with still-high wage growth in 2008, further reduced profitability and raised the specter of increased bankruptcies. This, in turn, has contributed to rising past-due loans and is likely to affect bank profitability.

5. Aggregate balance sheet analysis demonstrates Estonia's vulnerability to foreign exchange risk. The country's net international investment position reached minus 77 percent of GDP in September 2008, 60 percent of which is explained by the banking sector's net foreign liability position. The bulk of that position (47 percent of GDP) is foreign-currency (FX) denominated. While the banks' FX exposure to nonresidents is more than covered by their net FX credit position vis-à-vis households and corporates, the latter's FX exposures are largely unhedged. ${ }^{4}$ So long as the currency board arrangement holds, these exposures would not pose a significant risk.

\footnotetext{
${ }^{3}$ Inflation averaged 7 percent during 2007 and 11 percent in 2008.

${ }^{4}$ Corporate FX earnings (for which data was unavailable) could enable that sector to continue servicing at least part of its FX exposure, but the same does not hold for households. Remittances remain very small—a few hundred million euros per year.
} 
Figure 2. Estonia: Average Apartment Price, 2000Q1-2008Q1 (Share of Monthly Wages [2000Q1=100])

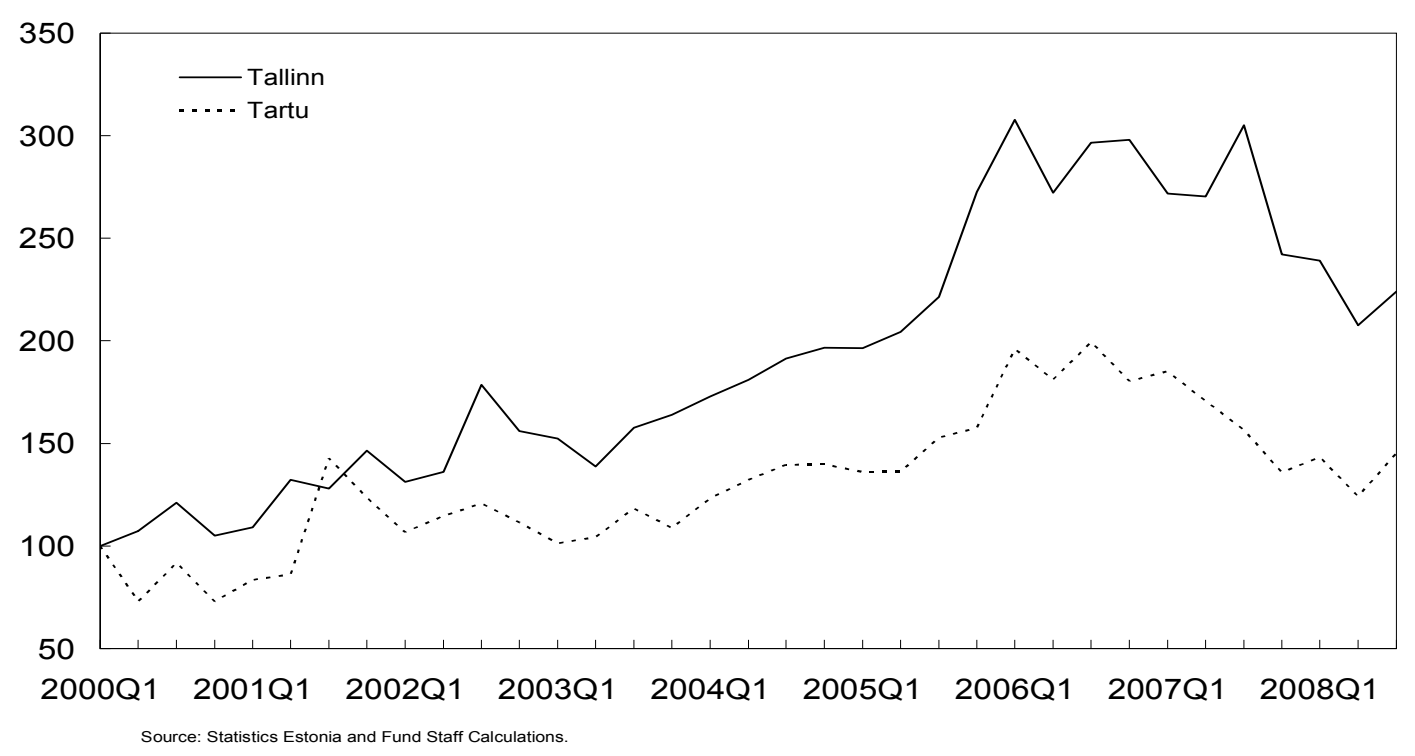

Figure 3. Estonia: Number of Apartment Transactions and Median Price, Jan. 2004-Nov. 2008

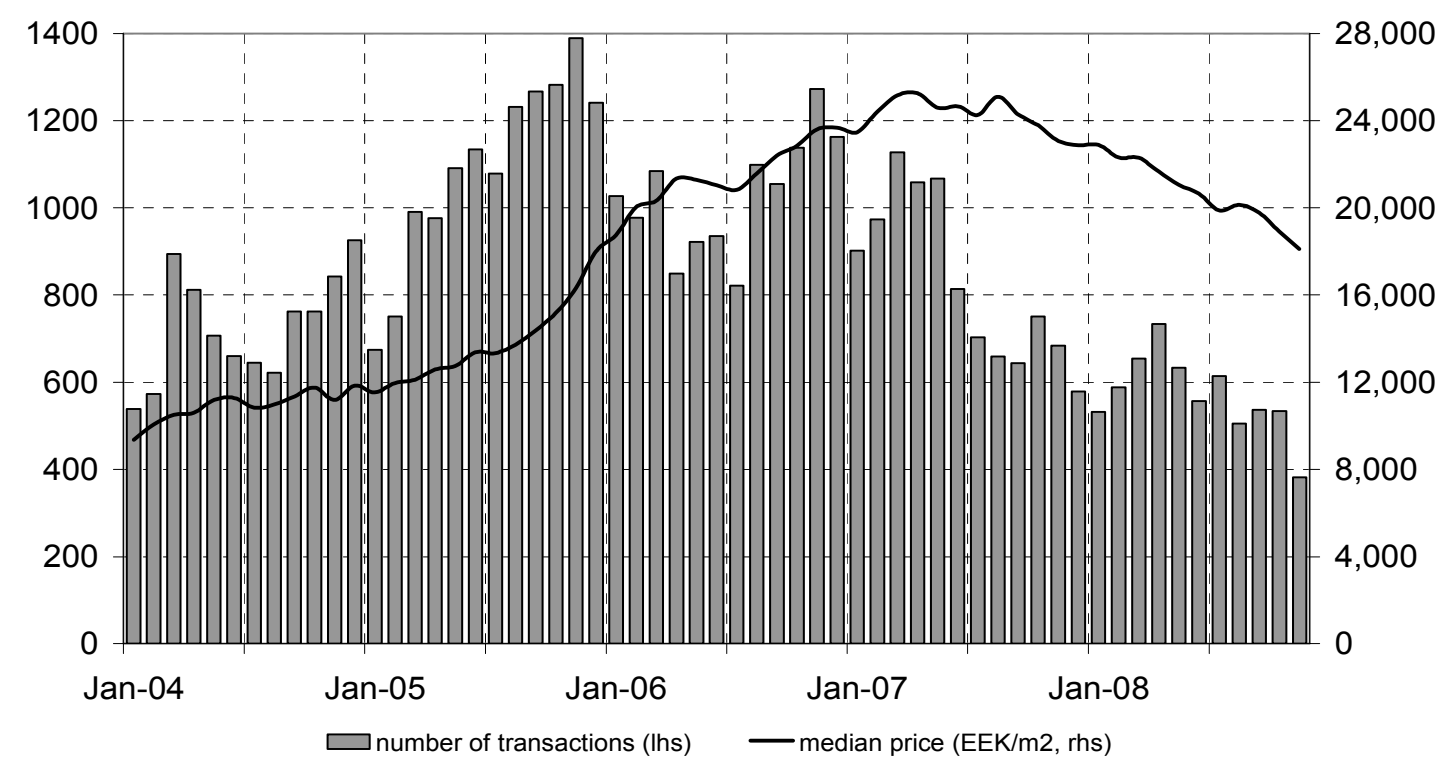

Source: Land Board Data 
Figure 4. Estonia: Contributions to Inflation, Dec. 1999-Nov. 2008

(Year-on-Year Percent Change)

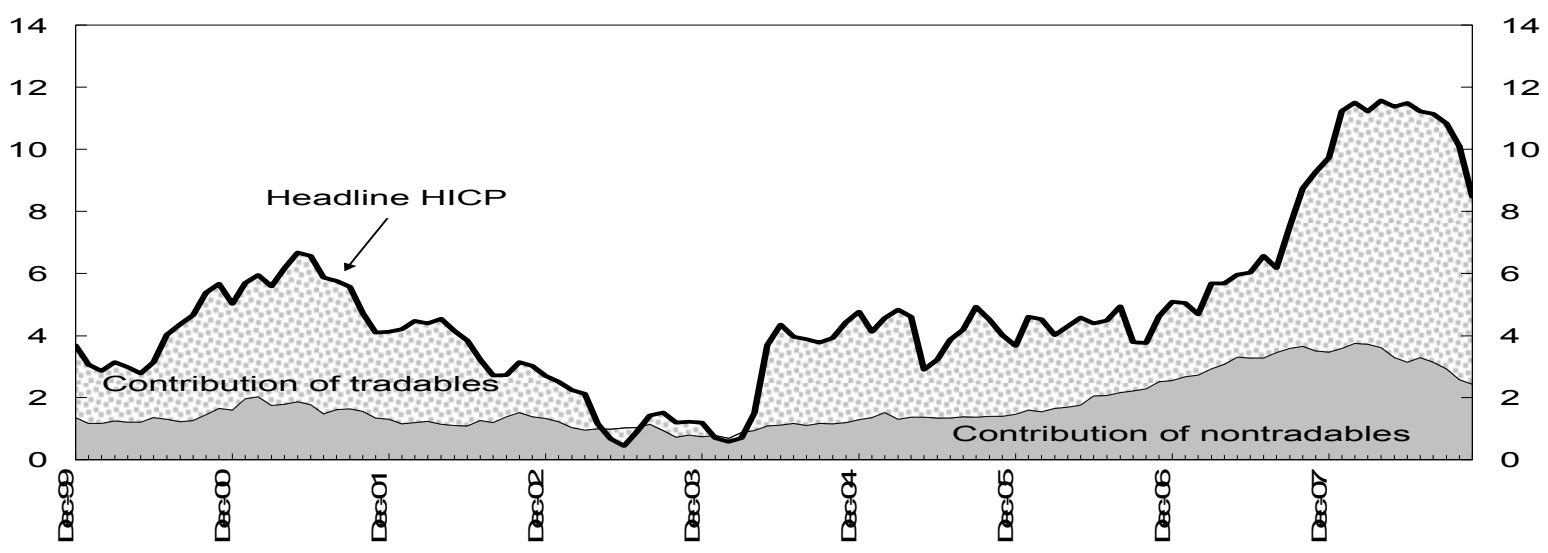

6. Liquidity risk is also a concern. Banks' liquid exposures reached 75 percent of GDP (over 12 billion euros), which dwarfs the net liquid asset positions of the government and the central bank combined (9.5 percent of GDP, equivalent to 1.5 billion euros) (Table 1, Figure 5, and Appendix III). The main reason for this large exposure of banks is the concentration of household loans in mortgages, which have long maturities, leaving only 28 percent of banks' short term liabilities covered by liquid assets. Given that under the currency board arrangement, the central bank can only look to its short term reserves as a source of liquidity, including these would increase the coverage ratio to 38 percent. ${ }^{5}$ It should be noted that changes in the methodology used in preparing the data treat all interbank borrowings as short-term. In fact, about 40 percent of the banking sector's nonresident liabilities have maturities over 12 months. While this provides a temporary safety valve, there is still a significant mismatch in the maturities of bank assets and liabilities.

\section{These risks are mitigated to some extent by the fact that most of the liquidity} exposure of Estonian banks is to their Swedish parents. These parent institutions would (in most circumstances) be unlikely to cut off their subsidiaries' funding since they consider their operations in the Baltic States as strategic long-term investments. Nonetheless, these parent institutions themselves rely on international markets for their funding, so a broader shock in international markets or a loss of confidence in the viability of these parent groups could have a significant impact on Estonia.

\footnotetext{
${ }^{5}$ These calculations take the CBA as given. In the absence of a currency board, and setting aside concerns about inflation, what would matter is the foreign currency liquidity exposure, which for banks would be slightly higher because of extensive borrowing from parent banks in foreign currency-about 25 percent of their shortterm FX liabilities are covered by liquid FX assets - but would be more substantially strengthened by adding in the central bank's international reserves - the coverage ratio would rise to 46 percent.
} 
Table 1. Estonia: Sectoral Balance Sheet Exposures, September $2008^{12}$
(In percent of GDP)

\begin{tabular}{|c|c|c|c|c|c|c|c|c|c|c|}
\hline & \multicolumn{4}{|c|}{ Net Financial Asset Positions by Currency } & \multicolumn{6}{|c|}{ Liquidity Position by Currency } \\
\hline & \multirow[b]{2}{*}{ Kroon } & \multirow[b]{2}{*}{$\begin{array}{l}\text { Foreign } \\
\text { exchange }\end{array}$} & \multirow[b]{2}{*}{ Equity } & \multirow[b]{2}{*}{ Total } & \multicolumn{3}{|c|}{ Kroon } & \multicolumn{3}{|c|}{ Foreign exchange } \\
\hline & & & & & Assets & Liabilities & $\begin{array}{c}\text { Net } \\
\text { Position }\end{array}$ & Assets & Liabilities & $\begin{array}{c}\text { Net } \\
\text { Position }\end{array}$ \\
\hline Government & 4.3 & 8.3 & 17.2 & 30 & 4.7 & 0.0 & 4.7 & 4.7 & 1.6 & 3.1 \\
\hline Eesti Pank & -13.5 & 15.0 & -1.5 & 0 & 0.0 & 13.5 & -13.5 & 15.4 & 0.4 & 15.0 \\
\hline Banks & -5.1 & 31.1 & -22.2 & 4 & 11.5 & 31.7 & -20.1 & 18.4 & 73.7 & -55.3 \\
\hline Households & 10.8 & -26.7 & 16.5 & 1 & 19.1 & 0.4 & 18.6 & 4.3 & 0.2 & 4.2 \\
\hline Other private sector & 3.0 & -62.0 & -52.3 & -111 & 9.6 & 1.1 & 8.5 & 18.3 & 15.0 & 3.3 \\
\hline \multicolumn{5}{|c|}{ Banks' exposures by creditor and currency } & \multicolumn{6}{|c|}{ Corporates' exposures by creditor and currency } \\
\hline & Kroon & $\mathrm{FX}$ & Equity & Total & & & Kroon & $\mathrm{FX}$ & Equity & Total \\
\hline Government & -4 & 1 & 0 & -4 & Governn & & 0 & -3 & -15 & -18 \\
\hline Eesti Pank & 10 & 0 & 0 & 10 & Eesti $\mathrm{Pa}$ & & 0 & 0 & 0 & 0 \\
\hline Households & -8 & 36 & 0 & 28 & Househ & & 0 & 0 & -8 & -8 \\
\hline Other private sector & -3 & 42 & -9 & 30 & Banks & & 3 & -42 & 9 & -30 \\
\hline Nonresidents & 0 & -47 & -14 & -61 & Nonresi & & 0 & -18 & -38 & -56 \\
\hline \multicolumn{5}{|c|}{ Households' exposures by creditor and currency } & & & & & & \\
\hline & Kroon & $\mathrm{FX}$ & Equity & Total & & & & & & \\
\hline Government & 0 & 0 & 0 & 0 & & & & & & \\
\hline Eesti Pank & 3 & 0 & 0 & 3 & & & & & & \\
\hline Other private sector & 0 & 0 & 8 & 8 & & & & & & \\
\hline Banks & 8 & -36 & 0 & -28 & & & & & & \\
\hline Nonresidents & 0 & 9 & 8 & 18 & & & & & & \\
\hline
\end{tabular}

Source: Authorities data and staff estimates.

1/ Liquidity Position refer to positions in short-term (less than 1 year) assets and liabilities.

2/ Net Financial Asset Position refer to total (short-term and long-term) assets minus total (short-term and long-term) liabilities.

Figure 5. Estonia: Net FX Liquidity Position by Sector, $2007^{1 /}$ (In percent of GDP)

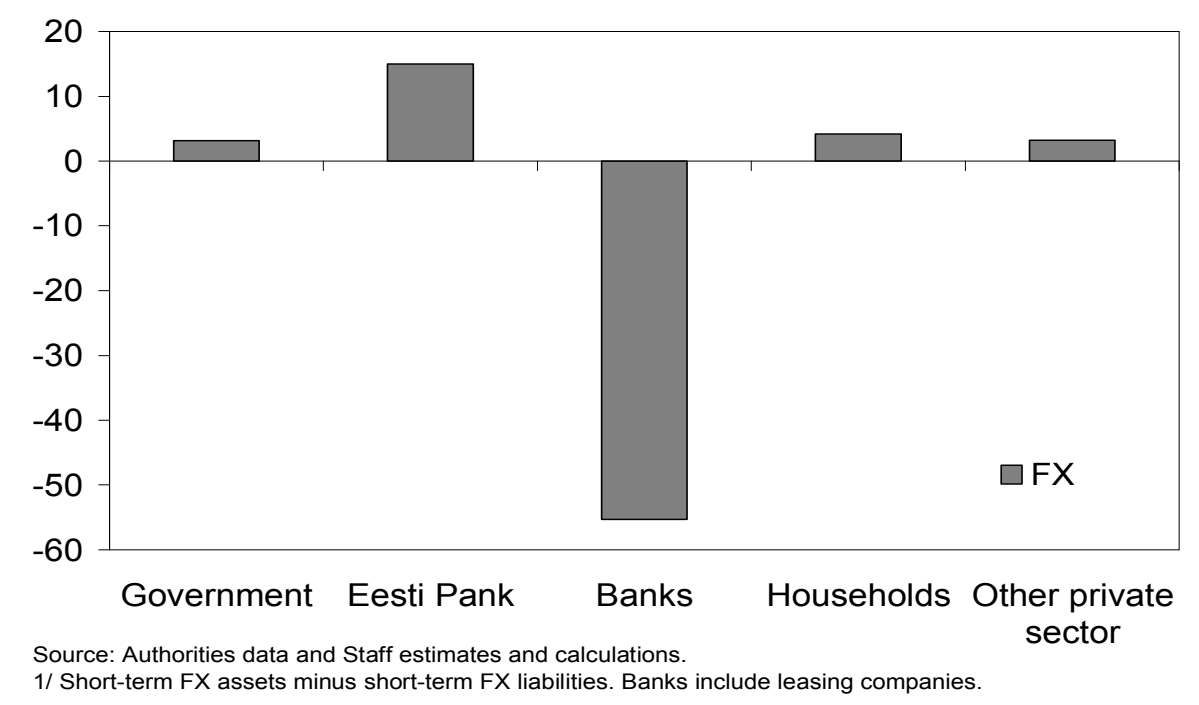




\section{B. Financial Structure}

8. The banking sector is highly concentrated and foreign-owned. At 97 percent and 47 percent of GDP respectively, private sector bank credit and deposits are the most popular financial instruments, although pension funds assets are also growing in size. The banking sector, either through wholly owned subsidiaries or branches, is 96 percent controlled by Nordic institutions (Figure 6). It is highly concentrated, with two subsidiaries of Swedish banks - Swedbank and Skandinaviska Enskilda Banken (SEB) - holding over 68 percent of the sector's assets, and an additional 25 percent held by the branches of Nordea (Finland) and Danske banks in roughly equal shares. ${ }^{6}$ Swedbank-owned Hansapank also has subsidiaries in Latvia and Lithuania. ${ }^{7}$ The same financial institutions dominate the nonbank financial sector owning insurance, brokerage, and pension fund management companies. Market data suggest that the exposure of the Swedish parents of the two largest banks to the Baltics has become an important part of their balance sheets and during the first nine months of 2008 accounted for 28 percent of Swedbank's and 21 percent of SEB's profits.

\section{Banks have become increasingly more cautious in their lending and credit} growth has decelerated sharply. The growth of bank credit to the private sector, which had exceeded 60 percent (excluding leasing credit) in 2005-06, had dropped to $33^{1 / 3} 3$ percent by end-2007 (Figure 7) and continued to decline to about 10 percent for 2008. The decline was initially prompted by Estonia's two major banks after the February 2007 exchange crisis in Latvia raised awareness of the risk attached to their Baltic exposures. By mid-2007, however, the decline became increasingly demand-driven in the wake of a drop in consumer and business confidence. As a result, bank lending rates remained low although they increased in the last quarter of 2007 in the wake of global market developments. More recently banks have tightened credit standards, are requiring additional collateral, and have added a 3 percentage point risk premium to lending rates.

\section{Financial Stability Assessment}

10. The Estonian banking sector was relatively unaffected by the banking problems in Latvia, reflecting the relatively strong financial position of Estonian banks. Current financial indicators suggest a sound banking sector, and show relative strength in asset quality and earnings (Appendix IV). Profitability was among the highest in Europe, driven by volume growth as well as strong operational efficiencies. Estonian banks' favorable cost-toincome ratio ( 45 percent on average) derives, in part, from the fact that 95 percent of all bank transactions are done electronically. The recent problems in Latvia did not directly impact

\footnotetext{
${ }^{6}$ Danske acquired Finland's SAMPO Bank in February 2007 and turned the Estonia subsidiary into a branch in June 2008.

${ }^{7}$ In all three countries the bank is now operating under the Swedbank name.
} 
Estonian banks, especially since Latvia was able to maintain its exchange rate. That said, an Estonian bank experienced a deposit outflow, in part because of concerns about its parent bank's exposure to the Baltics.

\section{Figure 6. Estonia: The Banking Structure}

Two Swedish-owned banks dominate the Estonian banking system total assets.

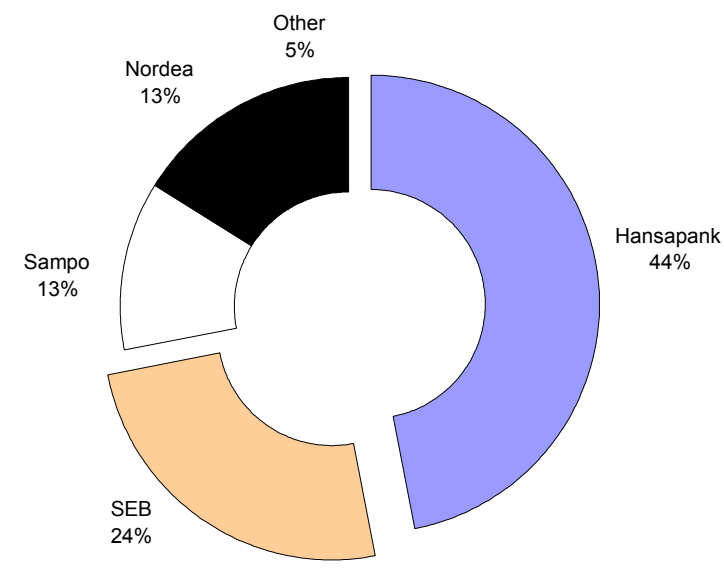

Source: National authorities and IMF staff estimates.
While Baltic subsidiaries account for an important share of total group assets (In percent)

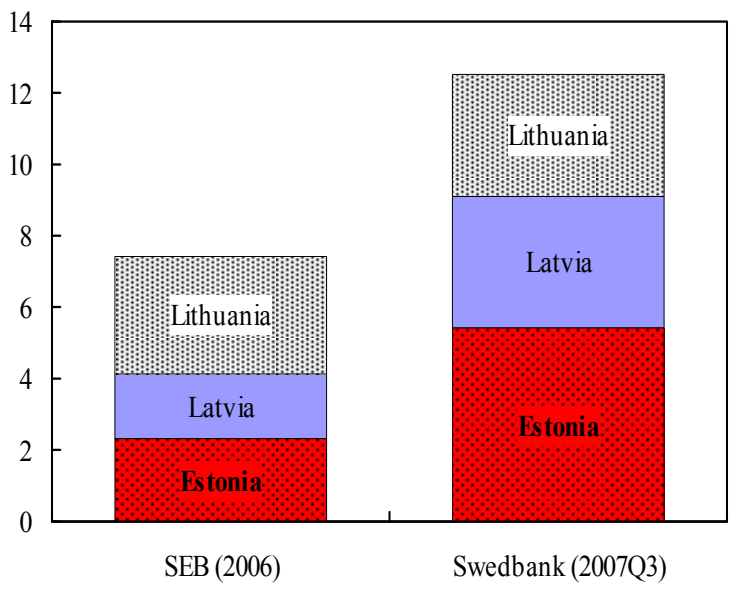

Figure 7. Estonia: Private Credit
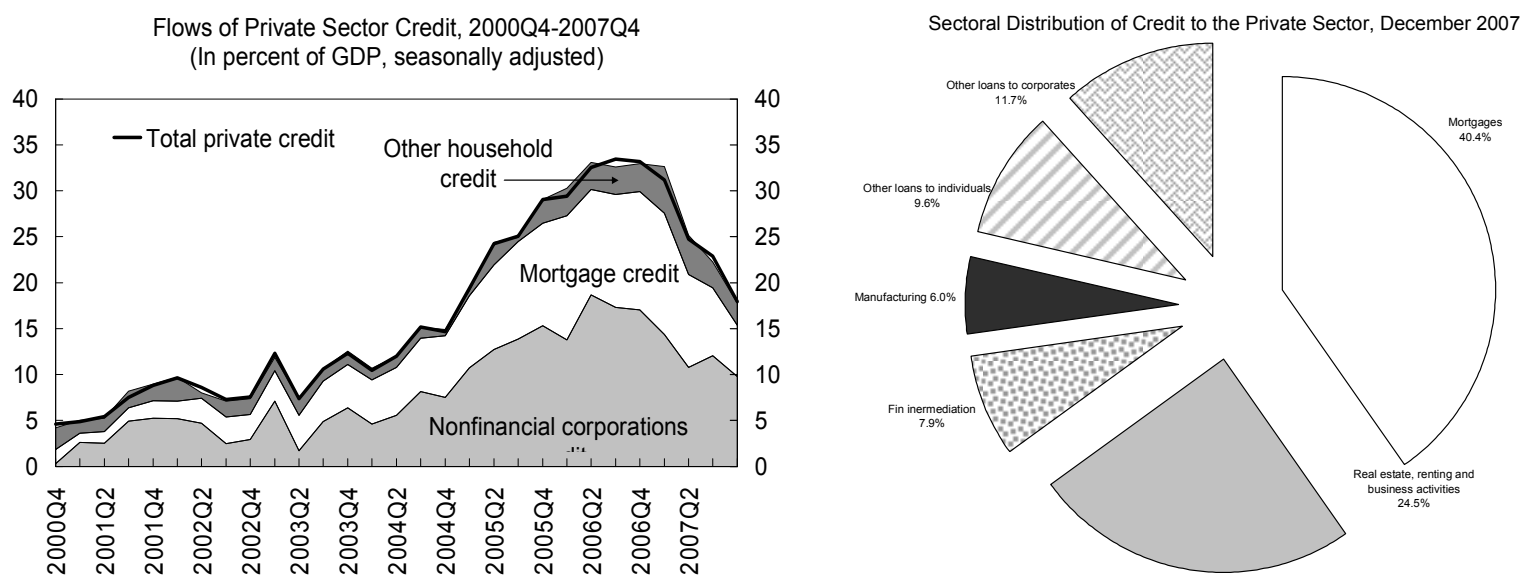

Source: National authorities and IMF staff estimates. 
11. The recession in Estonia has only just begun to impact the banking sector. The upswing in the economic cycle had brought exceptional profitability and asset growth to Estonian banks. Although the recession has now entered its second year, banks have remained profitable in the face of deteriorating credit quality and despite curtailing credit expansion as they have tightened underwriting standards and increased spreads in recognition of the risks; also, the average quality of the portfolio has remained good as the rapid increase in nonperforming loans (NPLs) was from a very low base. Current financial indicators suggest a sound banking sector, and show relative strength in asset quality and earnings (Appendix IV). NPLs have remained extremely low in recent years and compare favorably with other European countries even when using a conservative definition (60 days) of loans past due for Estonia (See Appendix V). ${ }^{8}$ The slowdown in economic growth has only just begun to suggest a future weakening of banking sector performance indicators, since these financial stability indicators tend to lag economic developments. The deterioration in bank liquidity ratios, especially the increasing reliance on external borrowing, is an important vulnerability.

12. Market-based indicators and financial accounts suggest that the vulnerability of Swedish parent banks has recently increased. Share prices have fallen substantially compared to the Nordic indices. ${ }^{9}$ In addition, Moody's KMV estimated that default probabilities for all three banks - SEB, Swedbank, Nordea - increased, though they are low. ${ }^{10}$ Capital ratios have been falling and especially for Swedbank, although they remain above the 8 percent minimum. Consequently, Swedbank was downgraded twice by Moody's during 2008 with its bank financial strength rating lowered to $\mathrm{C}+$ on October 1 and its credit rating lowered to Aa3. To a large extent these reductions reflected the bank's mortgage exposure in the Baltics (it derives 29 percent of total operating profits from the Baltics).

\section{Public doubts about the health of one of the Swedish parent banks spilled over to}

Estonia in the fall of 2008. In late September/early October Swedbank experienced a deposit outflow as a result of negative stories in the Swedish press. These accounts were reprinted in Estonia and led to a significant deposit outflow from the Estonian subsidiary (as well as from other subsidiaries in Baltic countries). It should be noted that the funds did not leave Estonia

\footnotetext{
${ }^{8}$ Most countries report loans as nonperforming when they are 90 days past due. The data for these countries has not been adjusted, resulting in a comparison of loans past due by 60 days for Estonia with those past due 90 days in other countries.

${ }^{9}$ While bank share prices have all fallen substantially relative to nonbank share prices, there has been some differentiation linked to exposure to the Baltics. SEB and Swedbank shares have fallen about 10 percent relative to the FTSE 300 bank index while Nordea and Danske have maintained their relative value.

${ }^{10}$ The increase is equivalent to a one-to-two notch downgrade in ratings (Swedbank's equivalent rating would be Ba1).
} 
but shifted to the two branches of other Nordic banks. A liquidity crisis was averted by the actions of the Swedish authorities who expanded the list of eligible collateral that could be pledged at the Riksbank and also encouraged Swedbank to use central bank borrowings to support liquidity needs throughout the group.

\section{A. Vulnerabilities}

14. Though capital is above the regulatory minimum, the level of bank capital had not kept pace with the exposures that typically accompany rapid loan growth. With the rapid expansion of banks' balance sheets, the level of capital as a percent of total assets (leverage ratio) had been steadily declining since 2000. Nevertheless, regulatory capital ratios have recently increased as a result of the introduction of International Financial Reporting Standards (IFRS), with provision coverage for NPLs having come down substantially, due to the restrictions on banks' ability to take forward-looking provisions.

\section{Moreover, with the introduction of Basel II, in 2008, capital buffers for} mortgages were reduced. The authorities changed the risk weight on mortgage lending to 60 percent from 100 percent previously in effect. While this change is consistent with the European capital requirements directive (CRD) that allows a 35 percent risk weight on residential mortgages, it is not required. The CRD allows national authorities to set higher risk weights if banks extend mortgages with loan-to-value (LTVs) greater than 75 percent, as is the case in Estonia. Therefore, in view of the weakening real estate market, retaining the 100 percent risk weight would have been more prudent.

16. Despite its overall strength to date, signs of an incipient weakening in asset quality have emerged. Specifically, although the share of gross NPLs is still low (1.5 percent of the total portfolio at end-September, 2008) (Figure 8), the steady increase in loans past due 30 days serves as a leading indicator of future increases in NPLs.

17. Lending concentration in the real estate sector is a cause for concern. Large individual borrower exposures, defined as exposures over 10 percent of capital, are limited and do not pose significant risks. But lending is heavily concentrated in the real estate sector. Mortgage underwriting standards were liberal, with some loans having being made at 90 percent of the purchase price of the property and with a debt service coverage ratio of 40 percent. Moreover, mortgages are typically denominated in euros with floating interest rates.

18. Banks are vulnerable to FX risk as some 86 percent of total loans are denominated in foreign currency (mostly euros). The banking sector is long in euros, with mortgage credit extended to the household sector nearly all euro denominated. Since 
Figure 8. Estonia: Nonperforming Loans

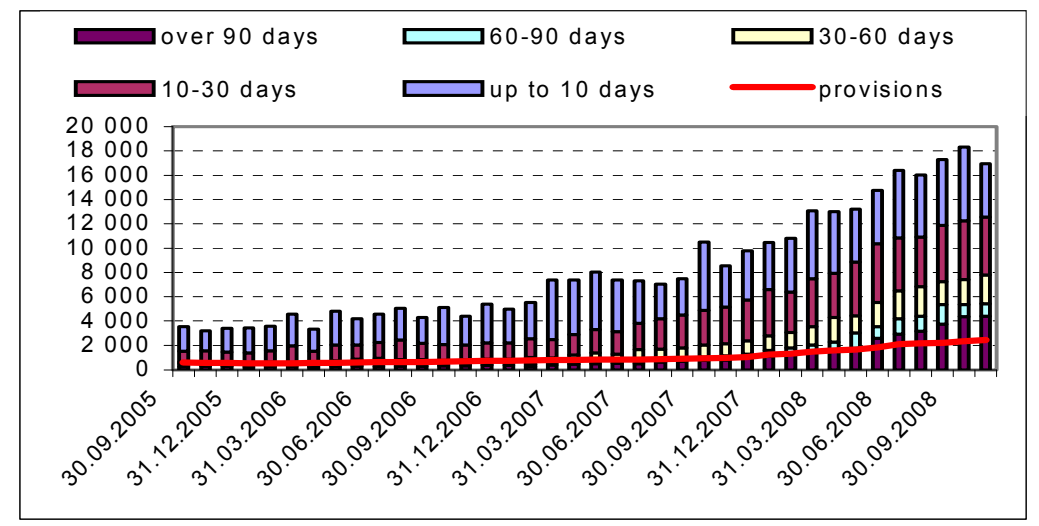

Banks' past due loans and provisions, mn EEK

households earn kroon income, these bank loans have converted FX risk to a credit risk. However, so long as Estonia is able to successfully maintain its CBA this risk is not significant. ${ }^{11}$

19. Additional vulnerabilities stem from banks' exposure to credit risks related to rising interest rates. Estonian banks have funded long-term mortgage loans with much shorter-term borrowings and have attempted to hedge their exposure by extending floating rate loans, linked to the Euro Interbank Offered Rate (Euribor). If rates rise sharply, banks will be faced with the choice of raising lending rates resulting in increased NPLs or squeezing margins and earnings. This concern is exacerbated by the high borrower debt service coverage ratios accepted by Estonian banks.

\section{Liquidity is a key risk with domestic banks highly dependent on borrowing from} their parents. Rapid credit expansion has been mostly financed by borrowing from parent banks, and the ratio of domestic deposits to bank loans fell below 50 percent at end-2007, though with tighter credit standards this ratio has declined only slightly during 2008 . Almost half of banking sector liabilities have remaining maturities of one month or less, ${ }^{12}$ whereas 46 percent of bank loans have maturities greater than ten years and about half of these have maturities that exceed 25 years. Given that their liquid assets cover 31 percent of their shortterm liabilities, banks' vulnerability to a liquidity shock is significant. In the case of the larger Estonian banks, this liquidity risk is inversely related to the ability and willingness of

\footnotetext{
11 The regulations limiting banks' net open positions are fully in line with international practice, though there are no restrictions on positions in euros.

${ }^{12}$ At end-October, 2008, liabilities of the banking sector with maturities of one month or less were 46 percent of total liabilities, and those with remaining maturities of 90 days or less were 59 percent of the total.
} 
their parents to continue funding them. ${ }^{13}$ As was the case during this past fall, this in turn may depend upon the ability and willingness of home country authorities to provide liquidity for subsidiaries of their banks.

\section{B. Stress Test Results}

21. Stress tests assessed the resilience of the system to extreme, but plausible, shocks using a combination of scenario and sensitivity analyses. As the authorities do not yet use credit VaR for the analysis, only expected losses were stressed. Scenario analysis was performed jointly with the BoE whose models are sufficiently robust to be relied on for such analysis. In addition BoE and EFSA assisted banks in bottom-up macroeconomic scenarios and credit risk sensitivity stress tests and these results were used to confirm the scenario results. Box 2 describes the stress testing methodology.

\section{The scenarios considered single and combined macroeconomic shock scenarios,} including a scenario based on historical experience. The scenarios, used during the mission in February 2008, were run out to 2011 and the impact on banks projected over this period. Additional detail and the underlying assumptions can be found in Box 2 and Appendix VI, but in summary the scenarios consisted of:

- $\quad$ Risk I, a sharp correction in real estate prices (30 percent) coupled with an initial 13 percent decline in investment but continued positive loan growth of almost 10 percent; $^{14}$

- $\quad$ Risk II, a sudden stop in credit inflows from parent banks leading to negative credit growth coupled with an almost 20 percent decline in investment and negative real GDP growth;

- $\quad$ Combination shock, involving a simultaneous sudden stop in capital inflows, a real estate price drop of 30 percent, a 50 percent increase in interest rates, and a slowdown of economic activity with negative real GDP growth; and

- Historical Scenario, a shock to exports and investments similar to the 1999 slowdown leading to an increase in NPLs to a recent peak level.

\footnotetext{
${ }^{13}$ Banks are required to meet a 15 percent reserve requirement and are not subject to an additional liquidity requirement.

${ }^{14}$ Since the real estate boom in Estonia appears to have been supported by rising personal income, and has been accompanied by an improvement in the quality of the housing stock, a 30 percent decline would be severe, and while arbitrary, seems reasonable. Furthermore, prices had already fallen 15 percent from their peak in 2006 when the tests were performed. Finally, a 50 percent decline in prices was included in the sensitivity analysis.
} 


\section{Box 2. Estonia: Description of the Stress Test Methodology}

Two types of stress tests were run: macroeconomic scenarios and sensitivity analyses. Staff of the IMF and BoE cooperated in the design of the four macroeconomic scenarios, two of which were run bottom-up by banks while all four were run by the BoE top down, using its aggregated financial reports data (Table 2). Separately, EFSA staff had designed and, in collaboration with the banks, implemented bottom-up six scenarios that tested the sensitivity of bank balance sheets to isolated shocks (Table 3). IMF staff also traced the separate impact of an exchange rate shock on banks' balance sheets (Table 3). The stress tests did not address any transmission effects of problems in other countries that could affect subsidiaries of Estonian banks.

Macroeconomic Scenarios. The scenarios covered the most plausible and, at the same time, most costly shocks for Estonia today - a collapse in real estate prices and a sudden stop in external funding. A combined scenario was also designed given the likelihood that these two shocks would happen together - perhaps one causing the other-and trigger a severe recession. The scenarios covered the year of the shock (assumed to be 2008) and three subsequent years. In performing the top-down tests, BoE staff first calculated NPLs for four years ahead under each scenario, using a model that defined NPLs as a function of nominal GDP growth and interest rates. ${ }^{1}$ In a second step, ROAA and risk-weighted assets were adjusted using expert judgment to reflect the credit growth and interest paths under the scenario. Profitability could thus be forecasted. Finally, assuming LGD is 100 percent and loan losses are written off the same year, capital and CARs were calculated.

Sensitivity Analyses. Univariate shocks were imposed on subsets of bank portfolios to assess sensitivity to credit risk. Income and real estate market shocks were considered. The banks ran the shocks on their portfolios and the EFSA aggregated the results by extrapolating to the whole system assuming normal distributions.

Foreign exchange risk. Because banks have long foreign currency positions, the staff's analysis focused on indirect foreign exchange risk - that is, the exposure of households and corporates, whose loans are mostly in euros, to exchange risk translating into credit risk to the banks. The analysis relied on expert judgment to translate exchange rate changes into changes in NPLs based on the econometric estimates and sensitivity analyses described above. An exchange rate shock of 30 percent would be equivalent to a 30 percent increase in monthly loan service payments in domestic currency, thus raising the burden on borrowers similar to an increase in interest rates.

${ }^{1}$ Several specifications were estimated, which differed by the set of explanatory variables as well as their lags. GDP growth and interest rates turned out to be significant across all specifications, but the fit for all models was relatively poor given the short-time series (consistent data was only available from 2000 onwards). This necessitated the use of expert judgment based on cross-country experience and the BoE's knowledge of the local banking climate.

\section{The scenarios were applied in top-down stress tests by the $\mathrm{BoE}$ using their} econometric models on the latest available bank-by-bank supervisory and macroeconomic data. In addition, two scenarios (Risk I and Risk II) were provided to the two largest banks to run using their own internal systems.

\section{The results of the macroeconomic scenario tests, summarized in Table 2, show} that under the combined shock, banks' capital would turn negative three years after the onset of a severe economic slowdown. In this scenario NPLs increase 14-fold to about 7 percent of total loans at the peak and banking system capital turns negative. Assuming the shock occurs in 2008, cumulative injections in 2010-2011 that would be required to bring the 
system to the minimum required capitalization of 10 percent would amount to 7 percent of GDP. Banks appear to be able to withstand the milder shocks of the other scenarios, though they would need to raise additional capital to comply with the regulatory minimum.

Table 2. Estonia: Stress Tests Summary: Macroeconomic Scenarios

\begin{tabular}{|c|c|c|c|c|c|c|c|}
\hline \multirow{3}{*}{$\begin{array}{c}\text { Type of stress } \\
\text { test }\end{array}$} & \multirow{3}{*}{$\begin{array}{c}\text { Variables } \\
\text { shocked/ Main } \\
\text { assumptions }\end{array}$} & \multirow{3}{*}{ Coverage } & \multirow{3}{*}{$\begin{array}{l}\text { Party that } \\
\text { performed the } \\
\text { test }\end{array}$} & \multicolumn{4}{|c|}{ Main results } \\
\hline & & & & \multicolumn{2}{|c|}{ NPLs (\%) } & \multicolumn{2}{|c|}{ CAR (\%) } \\
\hline & & & & yr 2 & yr 4 & yr 2 & yr 4 \\
\hline \multirow[b]{2}{*}{$\begin{array}{l}\text { Real estate } \\
\text { price shock } \\
\text { (Risk I) }\end{array}$} & \multirow[b]{2}{*}{$\begin{array}{l}30 \text { percent drop } \\
\text { in real estate } \\
\text { prices }\end{array}$} & All banks & $\begin{array}{c}\text { BoE } \\
\text { (Top down) }\end{array}$ & 2.8 & 2.0 & 9.7 & 6.8 \\
\hline & & $\begin{array}{l}\text { Two largest } \\
\text { banks (72\% } \\
\text { of system) }\end{array}$ & $\begin{array}{c}\text { Banks } \\
\text { (Bottom up) }\end{array}$ & \multicolumn{2}{|c|}{ n.a. } & \multicolumn{2}{|c|}{$\begin{array}{l}\text { Only marginal } \\
\text { decline below } \\
\text { regulatory } \\
\text { limit }\end{array}$} \\
\hline \multirow[b]{2}{*}{$\begin{array}{l}\text { Funding shock } \\
\text { (Risk II) }\end{array}$} & \multirow[b]{2}{*}{$\begin{array}{l}\text { Zero funding on } \\
\text { the margin from } \\
\text { parent banks }\end{array}$} & All banks & $\begin{array}{c}\text { BoE } \\
\text { (Top down) }\end{array}$ & 4.2 & 2.0 & 10.2 & 9.5 \\
\hline & & $\begin{array}{l}\text { Two largest } \\
\text { banks }(68 \% \\
\text { of system) }\end{array}$ & $\begin{array}{c}\text { Banks } \\
\text { (Bottom up) }\end{array}$ & \multicolumn{2}{|c|}{ n.a. } & \multicolumn{2}{|c|}{$\begin{array}{l}\text { Only marginal } \\
\text { decline below } \\
\text { regulatory } \\
\text { limit }\end{array}$} \\
\hline $\begin{array}{l}\text { Combined } \\
\text { shock }\end{array}$ & $\begin{array}{l}\text { Risk I + Risk II } \\
+200 \text { bps } \\
\text { increase in } \\
\text { interest rates }\end{array}$ & All banks & $\begin{array}{c}\text { BoE } \\
\text { (Top down) }\end{array}$ & 5.5 & 6.6 & 6.9 & -3.3 \\
\hline $\begin{array}{l}\text { Historical } \\
\text { scenario }\end{array}$ & $\begin{array}{l}\text { Exports and } \\
\text { investment } \\
\text { decline } \\
\text { mirroring } \\
\text { the } 1999 \text { crisis }\end{array}$ & All banks & $\begin{array}{c}\text { BoE } \\
\text { (Top down) }\end{array}$ & 3.9 & 2.4 & 10.0 & 5.3 \\
\hline
\end{tabular}

${ }^{1}$ Reports values of the corresponding variables in second and fourth years after the incidence of the shock. Initial values, at September 2007, for NPLs and the consolidated CAR ratios were 0.4 and 10.8 respectively.

25. Bottom-up results generally confirmed the top-down results. The bottom-up tests were run by the two largest banks using their own loan portfolios and client profiles. The results were not disclosed to staff for confidentiality reasons, but the banks reported much milder impacts of shocks in these tests, largely due to the lower loss given default (LGD) assumptions used - which were based on banks' own portfolios. While the banks were not able to run the combined shock scenario in time for the mission's work, they agreed that this would impose a greater challenge to their balance sheets than the isolated shocks.

26. Stress tests were updated during the December 2008 staff visit and generally supported the earlier results, though anticipated retained earnings for 2008 provided additional cushion. Several macro scenarios were tested: (i) a risk scenario that has GDP declining by 4.7 percent in 2009 and beginning a mild recovery in 2010; (ii) the same 
scenario but with interest rates being 300 bp higher during 2009-2011; and (iii) an extended recession scenario with a weak recovery (1 percent real growth) in 2011 . While, at the time of the February 2008 mission, this appeared to be a relatively extreme scenario, events since suggest that it is closer to that applying a baseline scenario. The ongoing global financial crisis and developments in Estonia suggest that applying a conservative assumption of loss given default of 100 percent to this scenario may be reflective of the further downside risks, especially since during the downturn following the Russian debt crisis, the loss given default (LGD) was only 42 percent. Assuming that the LGD were to be 100 percent, by 2011 the aggregate capital adequacy ratio (CAR) would fall below 8 percent under all scenarios and none of the banks would fail. If the LGD is only 42 percent, the sector only fails to meet regulatory requirements under a scenario that entails higher interest rates. Table 3 summarizes the results of these tests.

\section{Sensitivity analysis was performed by the EFSA on the impact of a decline in} incomes and a decline in collateral values. The analysis involved a significant increase in default rates on loans to individuals, especially on loans to individuals with high LTVs and assumed that banks could only sell collateral at a 50 percent discount. Sensitivity analysis performed on corporate clients assumed that each client dropped 2-3 notches on banks' internal rating scales and that the LGD is 45 percent. Residential real estate developers were assumed to face a 30 percent increase in construction costs and forced by the weak market to sell properties at a 30 percent discount to their budgeted sales.

\section{The results of the sensitivity analysis suggest a mild impact on banks'} capitalization, largely because of the large buffers provided by last years' profits. The effects of individual shocks are presented in Table 4. Losses are largest from the overall shocks to household and corporate incomes that could arise from a severe economic slowdown. However, reduced profits still cover a large share of the write downs (ranging from 0.5 to 4.7 billion EEK) and the effect on capital is moderate with only a few banks' capital falling below the 10 percent requirement, but by less then a percentage point. It should be noted, however, that a more plausible shock would likely entail a combination of two or more of the sensitivity scenarios, in which case the impact on bank capital would compound to a much larger effect than suggested by the last column of Table $4 .^{15}$

\section{Inasmuch as the banks do not have direct foreign exchange exposure, a foreign} exchange rate shock was modeled as a shock to the debt service capacity of households and corporates leading to a significant increase in NPLs. To gauge the sensitivity to an exchange rate shock a 30 percent depreciation in the Kroon was assumed, which would be equivalent to a 30 percent increase in monthly loan service, and with a weighted average loan maturity of 10 years, it could be approximated by an interest rate increase of 200 basis points. Assuming that GDP growth, credit growth and all other factors remain in line with the

\footnotetext{
${ }^{15}$ Similarly, were a combined shock accompanied by a depreciation in the Kroon the results would be worse.
} 
baseline forecast, NPLs were projected, using BoE's model, to increase to 6 percent of loans by end-2011. From a bottom-up perspective, given that a majority of loans in foreign

Table 3. Estonia: Stress Tests Summary: Additional Economic Downturn Scenarios $^{1}$

\begin{tabular}{|c|c|c|c|c|c|}
\hline \multirow[t]{3}{*}{ Scenario } & \multirow{3}{*}{$\begin{array}{c}\text { Key Assumptions } \\
\text { Main Variables }\end{array}$} & \multicolumn{4}{|c|}{ Main Results } \\
\hline & & \multicolumn{2}{|c|}{ NPLs (\%) } & \multicolumn{2}{|c|}{ CAR(\% } \\
\hline & & 2009 & 2011 & 2009 & 2011 \\
\hline \multirow{5}{*}{$\begin{array}{l}\text { Central Bank Risk } \\
\text { Scenario }\end{array}$} & \multirow{5}{*}{$\begin{array}{l}\text { GDP declines by } 4.7 \text { percent in } \\
2009 \text { and grows by } 1.5 \text { percent in } \\
2010 \text {. Credit growth remains } \\
\text { barely positive in } 2009 \text { and grows } \\
\text { by } 2 \text { percent in } 2010\end{array}$} & \\
\hline & & \multicolumn{4}{|c|}{$\operatorname{LGD}=42 \%$} \\
\hline & & 4.6 & 2.4 & 11.6 & 8.7 \\
\hline & & \multicolumn{4}{|c|}{ LGD $=100 \%$} \\
\hline & & 4.6 & 2.4 & 8.8 & 3.9 \\
\hline \multirow{4}{*}{$\begin{array}{l}\text { Central Bank Risk } \\
\text { Scenario with higher } \\
\text { interest rates }\end{array}$} & \multirow{4}{*}{$\begin{array}{l}\text { Same as above plus } 300 \text { bp } \\
\text { higher interest rates }\end{array}$} & \multicolumn{4}{|c|}{ LGD $=42 \%$} \\
\hline & & 5.7 & 3.4 & 11.1 & 7.6 \\
\hline & & \multicolumn{4}{|c|}{ LGD $=100 \%$} \\
\hline & & 5.7 & 3.4 & 7.7 & 1.4 \\
\hline \multirow{4}{*}{$\begin{array}{l}\text { IMF Staff Scenario of } \\
\text { more severe downturn } \\
\text { and with credit } \\
\text { contraction }\end{array}$} & \multirow{4}{*}{$\begin{array}{l}\text { GDP declines by } 5.0 \text { percent in } \\
2009 \text { and } 3.0 \text { percent in } 2010 \\
\text { before growing by } 3.0 \text { percent in } \\
2011 \text {. Credit contracts by } \\
14 \text { percent in } 2009 \text { and } 3 \text { percent } \\
\text { in } 2010 \text { before growing by } \\
1 \text { percent in } 2011 \text {, accompanied } \\
\text { by a } 270 \text { bp decline in interest } \\
\text { rates over the period. }\end{array}$} & \multicolumn{4}{|c|}{ LGD $=42 \%$} \\
\hline & & 4.6 & 2.9 & 13.4 & 10.5 \\
\hline & & \multicolumn{4}{|c|}{ LGD $=100 \%$} \\
\hline & & 4.6 & 2.9 & 10.6 & 5.3 \\
\hline
\end{tabular}

${ }^{1}$ The tests were run by the BoE. Reports values of the corresponding variables in second and fourth years after the incidence of the shock. Initial values, at September 2008, for NPLs and the consolidated CAR ratios were 1.6 and 12.9 percent respectively. 
Table 4. Estonia: Stress Tests Summary: Sensitivity Analysis

\begin{tabular}{|c|c|c|c|c|}
\hline $\begin{array}{c}\text { Type of stress } \\
\text { test }\end{array}$ & $\begin{array}{c}\text { Variables } \\
\text { shocked/ Main } \\
\text { assumptions }\end{array}$ & Coverage & $\begin{array}{c}\text { Party that } \\
\text { performed the } \\
\text { test }\end{array}$ & Main results \\
\hline $\begin{array}{l}\text { Income shock } \\
\text { to households } \\
\text { that hold } \\
\text { mortgages, } \\
\text { leading to } \\
\text { default }\end{array}$ & $\begin{array}{l}\text { Four scenarios } \\
\text { for default } \\
\text { leading to } \\
\text { foreclosures + } \\
\text { banks sell } \\
\text { collateral at } \\
50 \text { percent } \\
\text { discount. }^{1}\end{array}$ & $\begin{array}{l}58 \text { percent } \\
\text { of all } \\
\text { banking } \\
\text { sector } \\
\text { mortgages }\end{array}$ & $\begin{array}{l}\text { FSA in } \\
\text { collaboration } \\
\text { with banks } \\
\text { (Bottom-up) }\end{array}$ & $\begin{array}{l}\text {-Write-offs between } 1.3- \\
6.2 \text { percent of tested portfolio. } \\
\text {-When extrapolated to the } \\
\text { entire banking sector, } \\
\text { maximum write-off is about } \\
65 \text { percent of banks' } 2007 \\
\text { profits, and CAR remains } \\
\text { above } 9 \text { percent for each bank. }\end{array}$ \\
\hline $\begin{array}{l}\text { Credit quality } \\
\text { shock to all } \\
\text { corporates }\end{array}$ & $\begin{array}{l}\text { Corporates } \\
\text { downgraded 2- } \\
3 \text { notches on } \\
\text { banks' internal } \\
\text { rating scales + } \\
\text { LGD }=45 \%\end{array}$ & $\begin{array}{l}77 \text { percent } \\
\text { of the } \\
\text { banking } \\
\text { sector's } \\
\text { corporate } \\
\text { portfolio }\end{array}$ & $\begin{array}{l}\text { FSA in } \\
\text { collaboration } \\
\text { with banks } \\
\text { (Bottom-up) }\end{array}$ & $\begin{array}{l}\text {-Write offs amount to } 4 \text { percent } \\
\text { of tested portfolio. } \\
\text {-When extrapolated to the } \\
\text { entire banking sector, write- } \\
\text { offs are less than } 60 \text { percent of } \\
\text { banks' } 2007 \text { profits, and CAR } \\
\text { remains above } 9 \text { percent for } \\
\text { each bank. }\end{array}$ \\
\hline $\begin{array}{l}\text { Income shock } \\
\text { to residential } \\
\text { real estate } \\
\text { developers }\end{array}$ & $\begin{array}{l}30 \text { percent } \\
\text { decline in sale } \\
\text { price of } \\
\text { developments } \\
\text { (vis-à-vis } \\
\text { budgeted price) }\end{array}$ & $\begin{array}{l}66 \text { percent } \\
\text { of banks' } \\
\text { portfolio of } \\
\text { residential } \\
\text { real estate } \\
\text { developers }\end{array}$ & $\begin{array}{l}\text { FSA in } \\
\text { collaboration } \\
\text { with banks } \\
\text { (Bottom-up) }\end{array}$ & $\begin{array}{l}\text {-Write offs amount to } \\
4.9 \text { percent of tested portfolio. } \\
\text {-When extrapolated to the } \\
\text { entire banking sector, write- } \\
\text { offs are less than } 7 \text { percent of } \\
\text { banks' } 2007 \text { profits and CAR } \\
\text { remains above } 9 \text { percent for } \\
\text { each bank. }\end{array}$ \\
\hline $\begin{array}{l}\text { Exchange rate } \\
\text { shock }\end{array}$ & $\begin{array}{l}30 \text { percent } \\
\text { depreciation }\end{array}$ & All banks & IMF staff & $\begin{array}{l}\text {-NPLs increase to } 6- \\
10 \text { percent, and CAR could fall } \\
\text { to as low as } 5 \text { percent in the } \\
\text { first year. }\end{array}$ \\
\hline
\end{tabular}

\footnotetext{
${ }^{1}$ The four scenarios are a) 10 percent of clients with highest LTV lose job and default; b) 10 percent of clients randomly chosen across the LTV spectrum lose job and default; c) All households with LTV>81 percent and LSR>41 percent default on all loans; d) Shock to disposable income by -25 percent driving clients whose resulting loan service ratio (LSR) exceeds 55 percent to default.
} 
exchange are to non-export oriented sectors and to households with no proven foreign exchange income, these borrowers would have difficulty servicing the loans. Therefore, devaluation would be equivalent to a combination of two of the EFSA's sensitivity shocks: a shock to incomes by 25 percent and a downgrade of all corporates by $2-3$ notches. Pulling together the EFSA's results on these two shocks, NPLs increase between 6 and 10 percent under this combined scenario, reducing the aggregate CAR to about 5 percent in the first year. Subsequent effects would depend on the impact of the Kroon depreciation on the macroeconomy.

\section{Overall, despite the deterioration in the economic environment, absent a major} liquidity squeeze, Estonia's banking system should remain resilient. While the economic deterioration means that scenarios that had earlier been viewed as highly pessimistic are now closer to the baseline, Estonian banks will benefit from a likely drop in interest rates and the healthy gains in capital accrued during 2008, mitigating the effect of the global crisis on their income and balance sheet performance. That said, they remain vulnerable to a further intensification of global liquidity pressures that would result in rising interest costs to Estonian banks and to their borrowers.

\section{Risk Mitigation: Financial Safety Net and Crisis Management}

\section{Estonia has taken policy measures that provide at least a partial buffer against}

financial strain. These include requiring banks to maintain reserve requirements of 15 percent having a strong bank regulatory and supervisory framework that includes minimum capital requirements of 10 percent, higher than the 8 percent international norm, and a limited deposit guarantee scheme. Given its strict CBA, no emergency liquidity facility exists. However, given the vulnerabilities identified above, this framework may be insufficient to cope with a crisis and thus there is a need to develop further policy instruments to deal with market and other shocks. ${ }^{16}$

\section{A. Emergency Liquidity Assistance (ELA)}

32. Estonia has not had a policy or standing facility for ELA. Given the importance of such facilities for systemic stability, as a first step, BoE should formulate a policy for ELA, including the basis for taking a decision to grant ELA. Work has recently been done to identify the collateral required, the terms for lending, the interest to be charged, and documentation, and the BoE's Monetary Policy Committee has approved this framework. The policy should clearly take into account the constraints that BoE is faced with in providing ELA under the currency board arrangement, while recognizing the need to provide

\footnotetext{
${ }^{16}$ A list of the mission's main recommendations and the status of the authorities' implementation is presented in Appendix II.
} 
liquidity in a crisis situation. ${ }^{17}$ At present, the BoE intends, rather than establishing a policy for small banks, to decide the conditions under which ELA would be provided on a case-bycase basis. While central banks need to have the flexibility to respond to unusual situations it is preferable to establish basic polices on an ex ante basis. This would both serve to improve transparency and allow for speedier action should a bank need ELA.

33. In response to the recommendations of the FSAP-Update mission, the BoE has been developing a proposal for an ELA capability consistent with its CBA. Any such ELA will need to be coordinated with the home central banks of the parent banks to assure that the banking groups are not given access to excessive funding and to allow the home supervisor and central bank access to up-to-date information about the condition of the banking group. Given the limitations of Estonia's CBA, the ELA arrangement may require the close cooperation of neighbor central banks. In addition to these efforts, the BoE has developed operational procedures for the extension of liquidity to small banks from its excess reserves, on the basis of the haircut rules of the ECB.

\section{B. Bank Resolution Framework}

34. In addition to the general legislation for liquidation and bankruptcy, there are special provisions in the Credit Institutions Act (CIA). The EFSA is given the mandate not only to revoke a bank license but also to order a bank to submit a reorganization plan, or to order a total or partial suspension of a bank's activities ("a moratorium"). ${ }^{18}$ The EFSA is also one of the parties that may call on a court to issue an order for the liquidation or bankruptcy of a bank. A total moratorium is intended for a bank having a solvency problem, with the aim of gaining time to ascertain the reasons for and the nature of the problem and the scope for restoring solvency. The EFSA will appoint a moratorium administrator who manages the institution and administers and disposes of its assets. During a total moratorium, the bank will not make payments to depositors and other creditors.

\section{Given the structure of the Estonian financial sector, a more far-reaching} framework for resolving insolvent banks is called for. The framework should aim to protect the franchise value of the bank temporarily while gaining time for assessing its financial situation and prospects and also for taking various measures to resolve the situation in a manner that would avoid undermining confidence in the system or causing broader macroeconomic disruption. Statutory measures should allow for bank resolution techniques such as selling assets and liabilities, negotiating mergers or acquisitions, or creating a "bridge bank." To ensure proper legal process, the law should be amended to make it possible for the

\footnotetext{
${ }^{17}$ Other countries with currency boards, such as Lithuania, have put in place ELA facilities with strict restrictions on their use.

${ }^{18}$ A partial moratorium is only used if there is a need to stop the bank from engaging in a specific service or practice and is typically not used to address solvency problems.
} 
authority responsible for operating the resolution framework to assume the ownership of an insolvent bank without prior compensation to the shareholders. The shareholders should have the right of appeal to a court and may receive compensation if the court finds that the bank was not insolvent. However, the law should also make it clear that an appeal by the shareholders cannot delay the taking over of the bank by the authorities. ${ }^{19}$

\section{The authorities have informed staff that they plan to submit legislation aimed at broadening the resolution framework to parliament early this year. In response to} recommendations made by the FSAP-Update mission, the Ministry of Finance (MoF) is exploring options for revising the moratorium, resolution, and bankruptcy regimes to provide greater flexibility in resolving an insolvent bank. Included could be measures to expedite the removal of bank officers, clarify the treatment of shareholders' governance and property rights in the resolution process, and expedited examination processes.

\section{Deposit Guaranty Scheme}

37. Estonia has deposit insurance that is limited to $\mathbf{€ 5 0 , 0 0 0}$. The limited deposit guarantee program in Estonia has been in place since 2002. In response to the recent crisis, on October 23, 2008 the deposit insurance limit was raised from $€ 20,000$ and the 10 percent coinsurance feature was dropped. ${ }^{20}$ The new level of coverage fully covers more than 90 percent of total deposits (by value) in the banking sector. ${ }^{21}$

38. The Guarantee Fund relies solely on premiums charged banks. Banks pay quarterly premiums to the Fund at a flat rate of 0.125 percent of the amount of each bank's guaranteed deposits. The accumulated amount of premiums is presently EEK 1.8 billion. The authorities' target is to have the Fund reach 2 percent of the amount of guaranteed deposits (equivalent to EEK 1.8 billion at September 2008, under the old level of coverage). at which time levies on the insured institutions may be reduced. No action to reduce premiums has been taken. At 2 percent of guaranteed deposits the fund would be sufficient to cover guaranteed deposits at all but the two largest banks. ${ }^{22}$

\footnotetext{
${ }^{19}$ While the principles of the Civil Procedures Code and the Administrative Law allow court orders to be carried out pending an appeal, it is less clear whether this applies to the initial appeals to a court of supervisory sanctions, especially orders to revoke a license.

${ }^{20}$ The increase in coverage is consistent with the ECOFIN decision taken on October 7, 2008. The Estonian legislation was made retroactive to October 9, 2008 for consistency.

${ }^{21}$ Following EU rules, deposits at branches of foreign banks are covered by the home country deposit insurer.

${ }^{22}$ A fund of EEK 2 billion could pay out to depositors the full amount of guaranteed deposits, less the 10 percent coinsurance at all but the two largest banks. The size of guaranteed deposits at each of the two largest banks is larger than the size of the Fund.
} 
39. There are several deficiencies in the deposit guarantee framework that could undermine confidence in the financial sector and defeat one of the goals of deposit insurance, namely to discourage bank runs. These are:

- $\quad$ The Fund may only be used for payments to bank depositors and not for facilitating resolutions of banks. ${ }^{23}$ As a result any resolution of an insolvent bank, other than a straight liquidation and depositor payout will require the use of taxpayer funds.

- To be a credible guarantor, the Fund must be able to compensate claimants more quickly. Currently, the guarantee fund is required to pay within three months and begin the process in 30 days. This period could, and should, be shortened by various technical arrangements such as requesting that credit institutions structure their reporting systems in such a way that the information can be used for payouts from the Fund with a minimum of manual handling. Time could also be saved by having prepared arrangements with the government and Parliament so that the Fund can obtain loans or guarantees speedily. The MoF indicated that they are pursuing these recommendations, though with respect to shortening the required pay-out period they indicated they will follow the lead of the EU. To date there has been no legislative initiative to provide the deposit guarantee fund with a back-up line of credit from the government.

- The target amount set for the fund is insufficient and should be increased. While there are no international standards for the size of deposit guarantee funds, the current target ratio appears reasonable when compared to that in other countries, though lower than that in some neighboring countries. However, given the concentrated structure of the Estonian banking system, it appears inadequate. The fund would be insufficient to either cover insured depositors or facilitate a resolution should one of the two large banks become insolvent. Based on international experience, a ratio of 4 percent should provide sufficient funds to facilitate an orderly resolution of these banks by covering the negative net worth (though not guaranteed deposits). (See section B above).

\section{Crisis Management}

40. The Estonian authorities have taken some measures to enhance their crisis management capabilities. A wide range of Memoranda of Understanding (MoUs) exists among domestic government agencies and with all relevant foreign counterparties, mainly setting out the modalities for information sharing and cooperation and the various roles and mandates of the authorities in a crisis situation. The content of the MoUs have become increasingly sophisticated and detailed. The MoU concluded in late-2006 between the MoF,

\footnotetext{
${ }^{23}$ The same restriction also applies to investment funds and pension funds.
} 
the BoE, and the EFSA includes, for instance, the creation of a high-level committee that already meets in non-crisis times to discuss issues aimed at strengthening crisis preparations. There are also international bilateral and multilateral MoUs such as between the central banks of the Baltic countries and the Swedish central bank. The Estonian authorities also participate in EU crisis management initiatives, such as the April 2008 MOU. The Estonian authorities have conducted crisis simulation exercises, both internationally and domestically.

41. There would be considerable merit in conducting a crisis simulation that assumes problems at one of the larger Estonian banks active within the Baltics. The emphasis of the exercise should be to identify policy weaknesses, communication problems, and needed information. It also could include authorities from the other Baltic nations and the Swedish home authority in a manner similar to the recently completed Nordic-Baltic exercise. A specific area of focus should be on the information flow between the Baltic countries.

42. In December 2008, the authorities submitted to Parliament legislation that would speed up decision-making during a crisis, while still allowing the legislative branch a say in the use of fiscal resources. Specifically the legislation would reduce the number of readings of crisis legislation from three to one, hence allowing very speedy passage. The legislation also clarifies that the state reserve can be used to address a financial crisis. The authorities expect that this legislation will be enacted in January, 2009.

\section{Financial SECTOR SUPERVISION}

\section{A. Bank Supervision}

43. Financial sector supervision is conducted by the EFSA in cooperation with the MoF and BoE. The EFSA is an integrated supervisory authority overseeing the whole financial sector, including credit institutions, insurance companies, investment firms, fund management companies, and the capital market. The MoF is responsible for drafting legislation and issuing secondary legislation (regulations) for the insurance and securities sectors while the BoE issues banking regulations.

44. The EFSA's supervisory capacity appears to have improved significantly since its establishment in 2002. With the unification of the three separate supervision bodies into a consolidated supervision authority, operational independence of financial supervision (especially securities and insurance supervision) was strengthened.

45. Most of the weaknesses identified in the Basel Core Principles for Effective Banking Supervision (BCP) assessment performed during the 2000 FSAP have been addressed.$^{24}$ Legal protection was provided to the supervisory agency and its staff in 2002 with the enactment of the EFSA Act and amendments to the State Liability Act, addressing

${ }^{24}$ See Appendix I. 
the only area of "noncompliance" with the BCP. Most employees have participated in various internal and external training sessions on the financial sector and its supervision including Basel II to increase their professional skills. However, with the demands of Basel II implementation, staff is stretched.

46. The capital adequacy regime in Estonia is in line with international standards and consistent with the EU Capital Requirements Directive. In December 2006, the new capital adequacy regime was adopted, effective January 1, 2007. All banks chose the option to calculate the adequacy ratio in 2007 on the basis of the former system. From 2008, all credit institutions must start using one of the new approaches in calculating capital requirements under Basel II. For the implementation of the Pillar 2 framework from January 1, 2008, the EFSA issued advisory guidelines on "requirements to the internal capital adequacy assessment process (ICAAP)" which is based on principles of the Committee of European Banking Supervisors (CEBS) guidelines for Pillar 2.

47. The EFSA has been working with the Swedish home supervisor and Latvian and Lithuanian host supervisors on Basel II implementation issues, especially in relation to the approval process for Internal Ratings-Based (IRB) for credit risk and Advanced Measurement Approach (AMA) for operational risk. It has performed a number of joint visitations and inspections with the Swedish Financial Supervisory Authority (FSA) and other Baltic authorities. The EFSA has been making progress in implementing Basel II and appears to have the appropriate systems and policies in place to be successful.

48. Against this backdrop, the EFSA has signed a large number of arrangements to strengthen home-host cooperation significantly. As of 2007, the EFSA has signed fifteen home-host agreements with the supervisory authorities of nine different countries. It has agreements with Denmark, Finland, Germany, Latvia, Lithuania, Sweden, and Switzerland for banking and insurance; with the Cyprus and Netherlands for banking; and with Denmark, Finland, Latvia, and Lithuania for securities markets. Following the growing trend of using group-based home-host agreements to support generic MoUs, the EFSA has signed groupbased agreements with the Finnish FSA for the banking groups of Nordea and Sampo. In addition, the EFSA is currently participating in drafting the group-based home-host agreements concerning the two largest banks with the Swedish FSA and a MoU with the Bank of Russia.

49. There are no serious weaknesses in bank supervision. The EFSA appears to be conducting prudential supervision in an independent and professional manner in close cooperation with the BoE and MoF as well as home (especially Sweden) supervision authorities. Estonian financial and supervision regulations have been harmonized with EU rules. The systemically important banking groups seem to be closely monitored and continuously supervised by the EFSA. The current function-based organization structure of the EFSA is appropriate given Estonia's highly concentrated financial system. 
50. Given the challenges of implementing Basel II, the staffing of the EFSA may constrain its supervisory capacity going forward. The mission observed that the number of staff on-duty was low relative to international standards, especially given the need for more extensive on-site verification of reporting and documentation. ${ }^{25}$ There is also a need to strengthen the ethics provisions in the code of conduct for EFSA employees. In response to the mission's recommendations, the Supervisory Board of the EFSA authorized an increase in staffing of five positions and the authorities believe that the agency should be fully staffed by the second quarter of 2009. The EFSA has prepared draft revisions to the ethics rules but the need for them has not been agreed to by the central bank.

\section{B. Supervision of Private Pension Funds}

51. Despite the relatively small size of the economy, Estonia has been able to develop a growing pension fund industry, which operates very efficiently. This will likely be the fast growing segment of the financial sector in the future, in light of the 3 pillar pension system. This system includes a government provided pension (Pillar I), a mandatory private investment with fund managers of a portion of the government pre-funded pension (Pillar II), and a tax incentivised third pillar of private savings.

52. However, the current approach to supervision is insufficient to ensure that asset managers are acting in the best interest of the contributors. With the exception of integrity standards for asset managers and in some cases the internal control mechanismswhich are not tested or supervised — of the asset management company, there is nothing that the supervisor is actively doing to prevent potential fraud or misappropriation of assets of the pension fund by their managers. More than 80 percent of pension fund portfolios are invested abroad, with sizable participations in countries with soft regulation on issues such as frontrunning or self-dealing. Absent a stronger supervisory role by the EFSA, Estonian pension funds are at increased risk of wrongdoing by pension fund managers.

53. The supervisory framework for pensions should move from a compliance-based approach to a risk-based approach. The risk-based supervision approach provides a tool for understanding the market and addressing credit and operational risks of pension funds and asset management companies, which is not currently done.

\section{The EFSA should prohibit any tied-in sales in connection with the marketing of}

pension accounts. The competition of mandatory pension funds should not involve attractive offers on other products. In addition, the EFSA should request more transparency in the fees paid by the pension fund to intermediaries, including brokerage fees, asset management fees

\footnotetext{
${ }^{25}$ While the EFSA's approved staffing level may be appropriate, at any time about 10-15 percent of the staff are on leave of one sort or another. The mission judged the level of staff on-duty against the supervisory principles enunciated in the Basel Core Principles for Effective Bank Supervision.
} 
on Units in Collective Investments in Transferable Securities (UCITS) and other investment funds. The accounting system should also be improved, in order to be able to distinguish between the expenditures attributed to the pension system and those attributed to the other managed funds.

\section{Anti-Money Laundering}

55. MONEYVAL conducted its evaluation of Estonia's AML/CFT framework in February 2008 and the report was adopted at its plenary session in December. The evaluators concluded that Estonia's legal framework for AML/CFT is broadly in line with international standards. The report concluded that since the last MONEYVAL evaluation Estonia "has improved its legal framework for the criminalization of money laundering." Estonia has also ratified the United Nations Convention on the Suppression of Terrorist Financing. MONEYVAL concluded that "in recent years Estonia significantly improved its legal framework for criminalizing the financing of terrorism."

56. However, there are some elements of international requirements that are not sufficiently explicit within Estonia's legal framework. In particular, a major shortcoming is that the financing of individual terrorists is not criminalized. The authorities submitted legislation to parliament, on October 13, 2008 to address this issue, however, it has not yet passed. In terms of requirements for measures by financial institutions to prevent money laundering, MONEYVAL concluded that while the recent law "provides a sound legal basis concerning preventive measures" there are shortcomings as regards enhanced due diligence for some higher-risk transactions and in the sanctioning regime, in the event of violations. In addition, some shortcomings in the effectiveness of implementation of preventive measures were noted.

57. In accordance with the agreement between the Fund and MONEYVAL, once the full report is published, an executive summary will form the basis for a ROSC that will be sent to the Executive Board for information. 


\section{APPENDIX I. ESTONIA: UPDATE ON 2000 FSAP RECOMMENDATIONS}

\begin{tabular}{|c|c|}
\hline Recommendations of 2000 FSAP & Follow-up Actions by Authorities \\
\hline \multicolumn{2}{|c|}{ Supervisory Framework } \\
\hline \multicolumn{2}{|c|}{$\begin{array}{l}\text { The } 2000 \text { FSAP concluded that supervision had improved but recommended further reforms, which were largely } \\
\text { addressed with the establishment of the FSA in January } 2002 \text {. }\end{array}$} \\
\hline $\begin{array}{l}\text { Financial sector supervisors should have adequate } \\
\text { legal protection. }\end{array}$ & $\begin{array}{l}\text { Done. As reported in IMF Country Report 02/132, the FSA } \\
\text { Act (passed May 2001) and the State Liability Act } \\
\text { (enforced January 1, 2002) ensure the legal protection of } \\
\text { supervisors. }\end{array}$ \\
\hline $\begin{array}{l}\text { The supervisory institution should be a strong, } \\
\text { credible institution with operational and budgetary } \\
\text { autonomy. It should be independent, but also } \\
\text { accountable. }\end{array}$ & $\begin{array}{l}\text { Done. According to the FSA Act, operational and } \\
\text { budgetary autonomy are satisfied, and the FSA is able to } \\
\text { make judgments and take supervisory actions } \\
\text { independently, while remaining accountable to parliament. }\end{array}$ \\
\hline $\begin{array}{l}\text { The supervisory authority should have a sufficient } \\
\text { range of powers, at least equal to those of the central } \\
\text { bank, including the right to issue and revoke banking } \\
\text { licenses. }\end{array}$ & $\begin{array}{l}\text { Broadly addressed. The EFSA's powers adequately } \\
\text { include the right to issue and revoke banking licenses, but } \\
\text { secondary legislation can only be issued by the central } \\
\text { bank (banking sector) and MoF (securities and insurance } \\
\text { sectors). }\end{array}$ \\
\hline $\begin{array}{l}\text { Supervisory staff should not be overstretched. They } \\
\text { should be highly-qualified, able to conduct on-site } \\
\text { supervision, and handle possible new complex market } \\
\text { products. }\end{array}$ & $\begin{array}{l}\text { Broadly addressed. The EFSA comprises } 70 \text { staff which, } \\
\text { given the structure it has adopted from } 2005 \text {-that is, } \\
\text { organizing itself into functional units rather than the } \\
\text { traditional supervisory model of sectoral units-allows it } \\
\text { to conduct its operations without overstretching its staff. A } \\
\text { flexible salary structure allows it to be competitive vis-à- } \\
\text { vis the industry and to attract and retain high-quality staff. }\end{array}$ \\
\hline $\begin{array}{l}\text { Establish a self-regulatory organization (SRO) to } \\
\text { supervise the Savings and Loans Associations. }\end{array}$ & $\begin{array}{l}\text { Not done. An agency was established as a forum where } \\
\text { Savings and Loans Associations can interact, but it has no } \\
\text { supervisory functions. }\end{array}$ \\
\hline $\begin{array}{l}\text { The banking supervisory authority should sign a MoU } \\
\text { with the Securities Inspectorate. }\end{array}$ & $\begin{array}{l}\text { Not applicable. The Inspectorate was merged into the } \\
\text { FSA. }\end{array}$ \\
\hline $\begin{array}{l}\text { The regulatory framework does not give the Securities } \\
\text { Inspectorate adequate independence, authority, or } \\
\text { enforcement power. In particular, the Inspectorate } \\
\text { could not enforce penalties effectively. }\end{array}$ & $\begin{array}{l}\text { Not applicable. The Inspectorate was merged into the FSA } \\
\text { and the FSA Act ensures these characteristics. }\end{array}$ \\
\hline $\begin{array}{l}\text { Move to a risk-based supervisory approach in the } \\
\text { insurance sector and establish annual reporting } \\
\text { procedures for insurers on the capital adequacy } \\
\text { requirements on a consolidated basis. }\end{array}$ & $\begin{array}{l}\text { Done. Insurance was merged into FSA and banking } \\
\text { supervisory approach applies to the insurance sector as } \\
\text { well. }\end{array}$ \\
\hline
\end{tabular}




\begin{tabular}{|c|c|}
\hline Recommendations of 2000 FSAP & Follow-up Actions by Authorities \\
\hline Improve ability to supervise large financial groups. & $\begin{array}{l}\text { Done. With the } 2005 \text { change in its organizational structure, } \\
\text { the FSA is able to examine market players in a } \\
\text { consolidated perspective. }\end{array}$ \\
\hline $\begin{array}{l}\text { Provide stronger assurances of Deposit Guarantee } \\
\text { Fund's access to funding-e.g., government could } \\
\text { open an EEK } 700 \text { million automatic credit line or } \\
\text { issue a guarantee in that amount, with amount to be } \\
\text { reduced as the DGF resources reach its target level } \\
\text { ( } 3 \text { percent of insured deposits). }\end{array}$ & $\begin{array}{l}\text { Not addressed. While the DGF can borrow from the } \\
\text { government, or from the market with government } \\
\text { guarantees, no provision in the law provides assurances for } \\
\text { access to such funding. }\end{array}$ \\
\hline \multicolumn{2}{|c|}{ Regulatory Framework } \\
\hline $\begin{array}{l}\text { The revised loan loss provisioning regulation has been } \\
\text { drafted and should be implemented as soon as } \\
\text { possible. }\end{array}$ & $\begin{array}{l}\text { Done. As reported in IMF Country Report } 02 / 132 \text {, the } \\
\text { decree No. } 9 \text { by the Governor of the BoE on rules for loan } \\
\text { classification and loan-loss provisioning was signed on } \\
\text { June } 27,2000 \text {, and enforced from July } 1,2000 \text {. }\end{array}$ \\
\hline $\begin{array}{l}\text { Consider whether rules on the use of derivatives in the } \\
\text { insurance sector (in line with EU) are needed. }\end{array}$ & Done. Rules in line with the EU legislation are in place. \\
\hline $\begin{array}{l}\text { The new Insurance and Securities Law that was in } \\
\text { Parliament at the time of the } 2000 \text { FSAP should be } \\
\text { enacted as soon as possible }\end{array}$ & $\begin{array}{l}\text { Done. Law passed in 2001, and amended in } 2007 \text { to bring } \\
\text { it in line with EU legislation. }\end{array}$ \\
\hline $\begin{array}{l}\text { The tax distortion that likely constrains investment in } \\
\text { capital market instruments should be removed (the } \\
\text { distortion exists because the personal income tax is } \\
\text { not levied on deposit interest income while it is levied } \\
\text { on dividends and other interest taxable). }\end{array}$ & Done. The distortion is removed. \\
\hline \multicolumn{2}{|c|}{ Cross-Sectoral/Country Collaboration Issues } \\
\hline $\begin{array}{l}\text { Should sign MoUs on information sharing between } \\
\text { key host and home supervisors, including in Lithuania } \\
\text { and Sweden. }\end{array}$ & $\begin{array}{l}\text { Done. All relevant MoUs have been signed except a MoU } \\
\text { with Russia which is still in process. }\end{array}$ \\
\hline $\begin{array}{l}\text { Should sign MoUs with home supervisors of insurers } \\
\text { with affiliates in Estonia }\end{array}$ & $\begin{array}{l}\text { Done. MoUs signed with home supervisors cover all } \\
\text { activities of the financial groups. }\end{array}$ \\
\hline $\begin{array}{l}\text { Estonia should join IOSCO and adopt its guiding } \\
\text { principles }\end{array}$ & $\begin{array}{l}\text { Partly done. Estonia joined IOSCO in } 2001 \text { but the } \\
\text { relevant MoU is still in process. }\end{array}$ \\
\hline $\begin{array}{l}\text { Develop an agreed collaboration framework for } \\
\text { solvency and liquidity crises, which at a minimum } \\
\text { should cover communication channels and broad } \\
\text { division of responsibilities. }\end{array}$ & Done. (Through MoUs). \\
\hline \multicolumn{2}{|c|}{ Payment Systems } \\
\hline $\begin{array}{l}\text { Ensure the prompt and successful implementation of } \\
\text { the new payments system (which was planned from } \\
\text { end 2000). }\end{array}$ & $\begin{array}{l}\text { Done. A new system was put in place from } \\
\text { January } 21,2002 \text {, described in IMF Country Report No. } \\
02 / 132\end{array}$ \\
\hline $\begin{array}{l}\text { Establish clear rules dealing with participants' } \\
\text { financial risks. }\end{array}$ & $\begin{array}{l}\text { Not addressed. The authorities do not feel the need to } \\
\text { have such rules, given the small size of the system and the } \\
\text { effectiveness of relying on legal reserve requirements } \\
\text { monitoring and foreign exchange window activity. }\end{array}$ \\
\hline $\begin{array}{l}\text { Develop limits and guarantees to ensure that the } \\
\text { failure of one participant will not lead to a systemic } \\
\text { failure of the payment system. }\end{array}$ & $\begin{array}{l}\text { Done. Within the two-pronged payments system in place } \\
\text { since } 2002 \text {. }\end{array}$ \\
\hline
\end{tabular}




\begin{tabular}{|l|l|}
\hline \multicolumn{1}{|c|}{ Recommendations of 2000 FSAP } & \multicolumn{1}{|c|}{ Follow-up Actions by Authorities } \\
\hline $\begin{array}{l}\text { Strengthen the legal basis for payment instruments in } \\
\text { line with the new EU directive on electronic } \\
\text { payments. }\end{array}$ & $\begin{array}{l}\text { Done. The e-money institution act was passed in } \\
\text { October } 2005 \text { and enforced in January 2006, but no such } \\
\text { institution has been created yet. }\end{array}$ \\
\hline $\begin{array}{l}\text { Conduct oversight of the private card payment } \\
\text { organization. }\end{array}$ & $\begin{array}{l}\text { In progress. The authorities agree on the need to have } \\
\text { such oversight and are considering various options for } \\
\text { putting a system in place-they are participating in the } \\
\text { relevant EU-wide discussions on the scope and modalities } \\
\text { of private card payments supervision. }\end{array}$ \\
\hline
\end{tabular}




\section{APPENDIX II. ESTONIA: MAIN RECOMMENDATIONS}

\begin{tabular}{|c|c|c|c|}
\hline Sector & Priority & Recommendation & Status \\
\hline \multicolumn{4}{|l|}{ Short term } \\
\hline All & High & $\begin{array}{l}\text { Formulate a policy for ELA, including the basis for taking a decision to grant } \\
\text { ELA, the collateral required, the terms for lending and documentation. } \\
\text { Coordinate ELA policy with those of the major home countries, notably } \\
\text { Sweden. }\end{array}$ & A draft proposal has been prepared. \\
\hline Banking & High & $\begin{array}{l}\text { Assess the policies and measures of the relevant Estonian authorities for } \\
\text { crises, including one in which the Estonian banks are unable to obtain } \\
\text { liquidity from their parent. }\end{array}$ & Under consideration. \\
\hline Banking & High & $\begin{array}{l}\text { A crisis simulation exercise should be held. Such an exercise should include } \\
\text { Hansapank's Baltic subgroup and be conducted together with the other Baltic } \\
\text { authorities and the Swedish authorities. }\end{array}$ & Under consideration. \\
\hline Pension & High & $\begin{array}{l}\text { The MoF needs to complete the regulation of the payout phase of the pension } \\
\text { scheme including addressing potential moral hazard issues. }\end{array}$ & Completed. \\
\hline All & Medium & Increase staffing of the EFSA and strengthen code of conduct. & Staffing has been increased. \\
\hline Banking & Medium & Implement joint EFSA-BoE macroeconomic stress tests. & $\begin{array}{l}\text { There is communication } \\
\text { between the BFSA and BoE } \\
\text { on stress testing. }\end{array}$ \\
\hline Banking & Medium & $\begin{array}{l}\text { Conclude group-specific MoUs and ascertain that there are no expectation } \\
\text { gaps in the supervision of Hansapank's sub consolidated group in the other } \\
\text { Baltic countries and Russia. }\end{array}$ & $\begin{array}{l}\text { Swedish FSA is awaiting } \\
\text { CEBS to complete its review } \\
\text { of templates before drafting group } \\
\text { MoUs. }\end{array}$ \\
\hline Banking & Medium & Reconsider the coinsurance feature of the deposit guarantee scheme. & Coinsurance removed in Oct. 2008. \\
\hline Banking & Medium & $\begin{array}{l}\text { Consider ways to shorten significantly the payout period from the Guarantee } \\
\text { Fund. }\end{array}$ & $\begin{array}{l}\text { Consideration being given } \\
\text { in the contest of EU efforts. }\end{array}$ \\
\hline Pension & Medium & $\begin{array}{l}\text { The MoF should develop a set of minimum standards for asset management } \\
\text { for pension fund managers. }\end{array}$ & No action to date. \\
\hline Pension & Medium & Develop a framework for guiding the fee structure of pension fund managers. & No action; needs further analysis. \\
\hline \multicolumn{4}{|c|}{ Medium-term } \\
\hline Banking & High & $\begin{array}{l}\text { Draft legislation introducing a resolution framework that recognizes the } \\
\text { uniqueness of banks and allows the transfer of assets and liabilities of an }\end{array}$ & $\begin{array}{l}\text { Work is underway at the MoF } \\
\text { with a target of having legislation }\end{array}$ \\
\hline
\end{tabular}




\begin{tabular}{|c|c|c|c|}
\hline Sector & Priority & Recommendation & Status \\
\hline & & $\begin{array}{l}\text { insolvent bank without having to invoke the formal bankruptcy procedures. } \\
\text { Introduce legislation for appointing a temporary administrator of a bank. }\end{array}$ & prepared by Spring. \\
\hline Banking & High & $\begin{array}{l}\text { Strengthen the Guarantee Fund in various ways (i) Establish contingency } \\
\text { plans for ensuring the necessary liquidity for the Guarantee Fund in the case } \\
\text { of failure of one of the two major banks and for the ultimate financing of such } \\
\text { payments; and (ii) Increase the target for the fund to } 4 \text { percent of guaranteed } \\
\text { deposits. }\end{array}$ & $\begin{array}{l}\text { The expedited procedures in the } \\
\text { legislation submitted to parliament may } \\
\text { provide for liquidity in a crisis. }\end{array}$ \\
\hline Pension & High & $\begin{array}{l}\text { Supervisory framework should move from compliance-based to a risk-based } \\
\text { approach. }\end{array}$ & No actions to date. \\
\hline Pension & High & $\begin{array}{l}\text { MoF should require institutional separation between asset management } \\
\text { company and depository/custodial services. }\end{array}$ & $\begin{array}{l}\text { Institutional separation not required. } \\
\text { Legislation to minimize conflicts } \\
\text { of interest has been prepared. }\end{array}$ \\
\hline All & Medium & Strengthen the ethics rules for EFSA employees. & $\begin{array}{l}\text { Strengthened ethics rules have been } \\
\text { drafted but await approval of } \\
\text { supervisory board. }\end{array}$ \\
\hline Banking & Medium & $\begin{array}{l}\text { The EFSA should conduct on-site verification of accuracy of reporting and } \\
\text { loan documentation every } 2-3 \text { years. }\end{array}$ & Being done. \\
\hline Pensions & Medium & Gradually relax investment limits on equity exposures. & Done. \\
\hline
\end{tabular}


APPENDiX III: Estonia: InTERSECtoral Asset AND LiabiLity Positions, SEPTEMber 2008

(In percent of GDP)

\begin{tabular}{|c|c|c|c|c|c|c|c|c|c|c|c|c|c|c|c|c|c|c|c|c|c|}
\hline \multirow{3}{*}{$\begin{array}{l}\begin{array}{l}\text { Intrument } \\
\text { Holder }\end{array} \\
\text { Central bank }\end{array}$} & \multicolumn{3}{|c|}{ Eesti Pank } & \multirow{2}{*}{\multicolumn{3}{|c|}{ 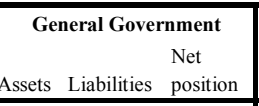 }} & \multirow{2}{*}{\multicolumn{3}{|c|}{ 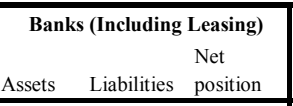 }} & \multirow{2}{*}{\multicolumn{3}{|c|}{$\begin{array}{c}\text { Other private sector } \\
\text { Net }\end{array}$}} & \multicolumn{3}{|c|}{ Of which: Households } & \multicolumn{3}{|c|}{ Nonresidents } & \multicolumn{3}{|c|}{ Sector's Overall Position } \\
\hline & Assets & & $\begin{array}{l}\text { ket } \\
\text { position } \\
\end{array}$ & & & & & & & & & $\begin{array}{l}\text { Net } \\
\text { position }\end{array}$ & \multicolumn{2}{|c|}{ Assets Liabilities } & \multirow[t]{2}{*}{$\begin{array}{l}\text { Net } \\
\text { position }\end{array}$} & Assets & Liabilities & $\begin{array}{l}\text { Net } \\
\text { position }\end{array}$ & $\begin{array}{l}\text { Total } \\
\text { Assets }\end{array}$ & $\begin{array}{c}\text { Total } \\
\text { Liabilities }\end{array}$ & $\begin{array}{l}\text { Total net } \\
\text { Position }\end{array}$ \\
\hline & & & & & & & & & & & & & & & & & & & & & \\
\hline In domestic currency & & & & 0.0 & 0.0 & 0.0 & 0.0 & 9.7 & -9.7 & 0.4 & 3.8 & -3.4 & 0.0 & 3.2 & -3.2 & 0.0 & 0.4 & -0.4 & 0.4 & 14.0 & -13.5 \\
\hline Short term & & & & 0.0 & 0.0 & 0.0 & 0.0 & 9.7 & -9.7 & 0.0 & 3.8 & -3.8 & 0.0 & 3.2 & -3.2 & 0.0 & 0.0 & 0.0 & 0.0 & 13.5 & -13.5 \\
\hline Medium \& Long term & & & & 0.0 & 0.0 & 0.0 & 0.0 & 0.0 & 0.0 & 0.4 & 0.0 & 0.4 & 0.0 & 0.0 & 0.0 & 0.0 & 0.4 & -0.4 & 0.4 & 0.4 & 0.0 \\
\hline In foreign currency & & & & 0.0 & 0.0 & 0.0 & 0.0 & 0.0 & 0.0 & 0.0 & 0.0 & 0.0 & 0.0 & 0.0 & 0.0 & 15.4 & 0.4 & 15.0 & 15.4 & 0.4 & 15.0 \\
\hline Short term & & & & 0.0 & 0.0 & 0.0 & 0.0 & 0.0 & 0.0 & 0.0 & 0.0 & 0.0 & 0.0 & 0.0 & 0.0 & 15.4 & 0.4 & 15.0 & 15.4 & 0.4 & 15.0 \\
\hline Medium \& Long term & & & & 0.0 & 0.0 & 0.0 & 0.0 & 0.0 & 0.0 & 0.0 & 0.0 & 0.0 & 0.0 & 0.0 & 0.0 & 0.0 & 0.0 & 0.0 & 0.0 & 0.0 & 0.0 \\
\hline Equity & & & & 0.0 & 2.0 & -2.0 & 0.0 & 0.0 & 0.0 & 0.0 & 0.0 & 0.0 & 0.0 & 0.0 & 0.0 & 0.4 & 0.0 & 0.4 & 0.6 & 2.0 & -1.5 \\
\hline General government & & & & & & & & & & & & & & & & & & & & & \\
\hline In domestic currency & 0. & 0.0 & 0.0 & & & & 4.8 & 0.4 & 4.3 & 0.0 & 0.0 & 0.0 & 0.0 & 0.0 & 0.0 & 0.0 & 0.0 & 0.0 & 4.8 & 0.4 & \\
\hline Short term & 0. & 0.0 & 0.0 & & & & 4.7 & 0.0 & 4.7 & 0.0 & 0.0 & 0.0 & 0.0 & 0.0 & 0.0 & 0.0 & 0.0 & 0.0 & 4.7 & 0.0 & 4.7 \\
\hline Medium \& Long term & 0. & 0.0 & 0.0 & & & & 0.1 & 0.4 & -0.4 & 0.0 & 0.0 & 0.0 & 0.0 & 0.0 & 0.0 & 0.0 & 0.0 & 0.0 & 0.1 & 0.4 & -0.4 \\
\hline In foreign currency & 0. & 0.0 & 0.0 & & & & 1.5 & 2.3 & -0.8 & 2.6 & 0.0 & 2.6 & 0.0 & 0.0 & 0.0 & 9.4 & 2.9 & 6.6 & 13.5 & 5.1 & 8.3 \\
\hline Short term & 0. & 0.0 & 0.0 & & & & 1.5 & 0.0 & 1.4 & 0.0 & 0.0 & 0.0 & 0.0 & 0.0 & 0.0 & 3.2 & 1.5 & 1.7 & 4.7 & 1.6 & 3.1 \\
\hline Medium \& Long term & 0. & 0.0 & 0.0 & & & & 0.1 & 2.3 & -2.2 & 2.6 & 0.0 & 2.6 & 0.0 & 0.0 & 0.0 & 6.2 & 1.3 & 4.9 & 8.8 & 3.6 & 5.2 \\
\hline Equity & 2. & 0.0 & 2.0 & & & & 0.0 & 0.0 & 0.0 & 15.2 & 0.0 & 15.2 & 0.0 & 0.0 & 0.0 & 0.0 & 0.0 & 0.0 & 17.2 & 0.0 & 17.2 \\
\hline Banks 1/ & & & & & & & & & & & & & & & & & & & & & \\
\hline In domestic currency & 9. & 0.0 & 9.7 & 0.4 & 4.8 & -4.3 & & & & 15.9 & 26.3 & -10.4 & 8.9 & 16.5 & -7.6 & 2.4 & 2.4 & 0.0 & 28.4 & 33.4 & -5.1 \\
\hline Short term & 9. & 0.0 & 9.7 & 0.0 & 4.7 & -4.7 & & & & 1.5 & 24.8 & -23.3 & 0.4 & 15.8 & -15.4 & 0.3 & 2.2 & -1.9 & 11.5 & 31.7 & -20.1 \\
\hline Medium \& Long term & 0. & 0.0 & 0.0 & 0.4 & 0.1 & 0.4 & & & & 14.3 & 1.5 & 12.9 & 8.5 & 0.7 & 7.8 & 2.1 & 0.2 & 1.9 & 16.9 & 1.8 & 15.1 \\
\hline In foreign currency & 0. & 0.0 & 0.0 & 2.3 & 1.5 & 0.8 & & & & 93.9 & 16.4 & 77.6 & 42.2 & 6.2 & 36.0 & 14.9 & 62.2 & -47.3 & 111.2 & 80.1 & 31.1 \\
\hline Short term & 0. & 0.0 & 0.0 & 0.0 & 1.5 & -1.4 & & & & 3.6 & 13.3 & -9.8 & 0.2 & 4.3 & -4.2 & 14.8 & 58.9 & -44.1 & 18.4 & 73.7 & -55.3 \\
\hline Medium \& Long term & 0. & 0.0 & 0.0 & 2.3 & 0.1 & 2.2 & & & & 90.4 & 3.0 & 87.3 & 42.0 & 1.9 & 40.2 & 0.1 & 3.3 & -3.1 & 92.8 & 6.4 & 86.4 \\
\hline Equity & 0. & 0.0 & 0.0 & 0.0 & 0.0 & 0.0 & & & & -7.7 & 1.1 & -8.8 & 0.0 & 0.0 & 0.0 & 11.2 & 25.1 & -13.9 & 4.0 & 26.2 & -22.2 \\
\hline Other private sector & & & & & & & & & & & & & & & & & & & & & \\
\hline In domestic currency & 3. & 0.4 & 3.4 & 0.0 & 0.0 & 0.0 & 26.3 & 15.9 & 10.4 & & & & & & & 0.0 & 0.0 & 0.0 & 30.1 & 16.3 & 13.8 \\
\hline Short term & 3. & 0.0 & 3.8 & 0.0 & 0.0 & 0.0 & 24.8 & 1.5 & 23.3 & & & & & & & 0.0 & 0.0 & 0.0 & 28.7 & 1.5 & 27.1 \\
\hline Medium \& Long term & 0. & 0.4 & -0.4 & 0.0 & 0.0 & 0.0 & 1.5 & 14.3 & -12.9 & & & & & & & 0.0 & 0.0 & 0.0 & 1.5 & 14.8 & -13.3 \\
\hline In foreign currency & 0. & 0.0 & 0.0 & 0.0 & 2.6 & -2.6 & 16.4 & 93.9 & -77.6 & & & & & & & 18.9 & 27.6 & -8.6 & 35.3 & 124.1 & -88.7 \\
\hline Short term & 0. & 0.0 & 0.0 & 0.0 & 0.0 & 0.0 & 13.3 & 3.6 & 9.8 & & & & & & & 9.3 & 11.6 & -2.3 & 22.6 & 15.2 & \\
\hline Medium \& Long term & 0. & 0.0 & 0.0 & 0.0 & 2.6 & -2.6 & 3.0 & 90.4 & -87.3 & & & & & & & 9.6 & 16.0 & -6.3 & 12.7 & 108.9 & -96.2 \\
\hline Equity & 0. & 0.0 & 0.0 & 0.0 & 15.2 & -15.2 & 1.1 & -7.7 & 8.8 & & & & & & & 25.7 & 55.0 & -29.3 & 26.8 & 62.6 & -35.8 \\
\hline Of which: Households & & & & & & & & & & & & & & & & & & & & & \\
\hline In domestic currency & 3. & 0.0 & 3.2 & 0 & 0 & 0 & 16.5 & 8.9 & 7.6 & & & & & & & 0.0 & 0.0 & 0.0 & 19.7 & 8.9 & 10.8 \\
\hline Short term & 3. & 0.0 & 3.2 & 0 & 0 & 0 & 15.8 & 0.4 & 15.4 & & & & & & & 0.0 & 0.0 & 0.0 & 19.1 & 0.4 & 18.6 \\
\hline Medium \& Long term & 0. & 0.0 & 0.0 & 0 & 0 & 0 & 0.7 & 8.5 & -7.8 & & & & & & & 0.0 & 0.0 & 0.0 & 0.7 & 8.5 & -7.8 \\
\hline In foreign currency & 0. & 0.0 & 0.0 & 0 & 0 & 0 & 6.2 & 42.2 & -36.0 & & & & & & & 9.3 & 0.0 & 9.3 & 15.5 & 42.2 & -26.7 \\
\hline Short term & 0. & 0.0 & 0.0 & 0 & 0 & 0 & 4.3 & 0.2 & 4.2 & & & & & & & 0.0 & 0.0 & 0.0 & 4.3 & 0.2 & 4.2 \\
\hline Long term & 0. & 0.0 & 0.0 & 0 & 0 & 0 & 1.9 & 42.0 & -40.2 & & & & & & & 9.3 & 0.0 & 9.3 & 11.2 & 42.0 & -30.8 \\
\hline Direct Investment & 0. & 0.0 & 0.0 & 0 & 0 & 0 & 0.0 & 0.0 & 0.0 & & & & & & & 8.2 & 0.0 & 8.2 & 16.5 & 0.0 & 16.5 \\
\hline Nonresidents & & & & & & & & & & & & & & & & & & & & & \\
\hline In domestic currency & 0. & 0.0 & 0.4 & 0.0 & 0.0 & 0.0 & 2.4 & 2.4 & 0.0 & 0.0 & 0.0 & 0.0 & 0.0 & 0.0 & 0.0 & & & & 2.8 & 2.4 & 0.5 \\
\hline Short term & 0. & 0.0 & 0.0 & 0.0 & 0.0 & 0.0 & 2.2 & 0.3 & 1.9 & 0.0 & 0.0 & 0.0 & 0.0 & 0.0 & 0.0 & & & & 2.2 & 0.3 & 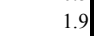 \\
\hline Medium \& Long term & 0. & 0.0 & 0.4 & 0.0 & 0.0 & 0.0 & 0.2 & 2.1 & -1.9 & 0.0 & 0.0 & 0.0 & 0.0 & 0.0 & 0.0 & & & & 0.7 & 2.1 & -1.4 \\
\hline In foreign currency & 0. & 15.4 & -15.0 & 2.9 & 9.4 & -6.6 & 62.2 & 14.9 & 47.3 & 27.6 & 18.9 & 8.6 & 0.0 & 9.3 & -9.3 & & & & 93.0 & 58.7 & 34.3 \\
\hline Short term & 0. & 15.4 & -15.0 & 1.5 & 3.2 & -1.7 & 58.9 & 14.8 & 44.1 & 11.6 & 9.3 & 2.3 & 0.0 & 0.0 & 0.0 & & & & 72.4 & 42.7] & 29.7 \\
\hline Medium \& Long term & 0. & 0.0 & 0.0 & 1.3 & 6.2 & -4.9 & 3.3 & 0.1 & 3.1 & 16.0 & 9.6 & 6.3 & 0.0 & 9.3 & -9.3 & & & & 20.6 & 16.0 & 4.6 \\
\hline Equity & 0. & 0.4 & -0.4 & 0.0 & 0.0 & 0.0 & 25.1 & 11.2 & 13.9 & 55.0 & 25.7 & 29.3 & 0.0 & 8.2 & -8.2 & & & & 80.1 & 37.3 & 42.8 \\
\hline
\end{tabular}




\section{APPENDIX IV. ESTONIA: FINANCIAL SOUNDNESS INDICATORS OF THE BANKING SECTOR, 2001-08}

\begin{tabular}{|c|c|c|c|c|c|c|c|c|}
\hline & 2001 & 2002 & 2003 & 2004 & 2005 & 2006 & 2007 & $\begin{array}{l}\text { Sept. } \\
2008\end{array}$ \\
\hline Regulatory capital as percent of risk-weighted assets & 14.39 & 15.26 & 14.51 & 13.37 & 11.72 & 13.16 & 14.78 & 18.34 \\
\hline Regulatory Tier I capital to risk-weighted assets & 14.44 & 13.57 & 13.44 & 12.92 & 11.71 & 10.04 & 10.55 & 12.83 \\
\hline \multicolumn{9}{|l|}{ Capital adequacy (on consolidated basis) } \\
\hline Regulatory capital as percent of risk-weighted assets & 14.80 & 13.38 & 12.50 & 11.47 & 10.72 & 10.79 & 10.84 & 12.88 \\
\hline \multicolumn{9}{|l|}{ Asset quality } \\
\hline Non-performing loans (NPL) as percent of gross loans & 1.33 & 0.80 & 0.37 & 0.26 & 0.20 & 0.18 & 0.44 & 1.55 \\
\hline NPL net of provisions as percent of Tier I capital & 5.16 & 3.26 & 2.32 & 2.03 & 1.22 & 1.56 & 3.82 & 13.91 \\
\hline Large exposures as percent of Tier I capital & 16.44 & 10.43 & 8.20 & 15.77 & 28.38 & 8.65 & 0.58 & 1.27 \\
\hline Gross income as percent of average assets & 6.08 & 4.90 & 4.61 & 4.67 & 4.13 & 3.78 & 4.72 & $\mathrm{n} / \mathrm{a}$ \\
\hline Net interest income as percent of gross income & 56.70 & 65.15 & 55.73 & 46.03 & 45.90 & 56.18 & 45.17 & 54.38 \\
\hline Non-interest income as percent of gross income & 43.30 & 34.85 & 44.27 & 53.97 & 54.10 & 43.82 & 54.83 & 45.62 \\
\hline Trading income as a percent of gross income & 17.94 & 28.35 & 23.72 & 18.16 & 18.51 & 18.57 & 17.79 & 11.18 \\
\hline Non-interest expenses as percent of gross income & 53.54 & 62.86 & 56.39 & 49.57 & 50.94 & 51.91 & 40.71 & 58.04 \\
\hline Personnel expenses as percent of non-interest expenses & 76.85 & 76.86 & 76.47 & 77.90 & 76.11 & 76.91 & 76.06 & 30.00 \\
\hline Spread between reference loan and deposit rates & 3.69 & 3.44 & 2.78 & 2.30 & 1.95 & 2.11 & 2.15 & $\mathrm{n} / \mathrm{a}$ \\
\hline \multicolumn{9}{|l|}{ Liquidity } \\
\hline Liquid assets as percent of total assets & 24.30 & 21.20 & 19.46 & 22.30 & 24.93 & 19.19 & 18.12 & 17.64 \\
\hline Liquid assets as percent of short-term liabilities & 37.30 & 32.24 & 30.10 & 39.17 & 39.46 & 31.98 & 34.89 & 31.43 \\
\hline Foreign currency loans as percent of total loans & 78.70 & 82.60 & 81.50 & 80.40 & 79.90 & 78.10 & 80.50 & 85.68 \\
\hline Foreign currency liabilities as percent of total liabilities & 45.61 & 46.95 & 51.43 & 57.80 & 59.90 & 59.80 & 68.05 & $\mathrm{n} / \mathrm{a}$ \\
\hline \multicolumn{9}{|l|}{ Duration of liabilities } \\
\hline $\begin{array}{l}\text { Net open position in foreign exchange as a percentage of Tier I } \\
\text { capital }\end{array}$ & 3.74 & 31.83 & 12.46 & 18.36 & 7.81 & 21.70 & 16.02 & 20.32 \\
\hline Net open position in equities as a percentage of Tier I capital & - & - & - & 49.83 & 58.77 & 51.97 & 65.54 & 59.29 \\
\hline
\end{tabular}

The Risk Classification of Banks' Loans

\begin{tabular}{|c|c|c|c|c|c|c|c|c|}
\hline Millions of Kroons & 2001 & 2002 & 2003 & 2004 & 2005 & 2006 & 2007 & $9 / 2008$ \\
\hline In order & 33829.47 & 44558.27 & 62642.08 & 85020.96 & 113488.68 & 161200.13 & 210601.60 & 225573.26 \\
\hline Under special surveillance & 4322.24 & 3428.58 & 4666.13 & 5599.81 & 9725.88 & 12828.75 & 21844.06 & 24758.59 \\
\hline Doubtful & 1177.24 & 884.98 & 1035.69 & 1246.62 & 1724.37 & 2992.31 & 5245.33 & 6795.74 \\
\hline Risky & 1024.72 & 715.54 & 449.88 & 261.81 & 252.09 & 365.70 & 805.97 & 1766.80 \\
\hline Hopeless & 339.65 & 372.95 & 362.66 & 410.75 & 262.90 & 284.00 & 658.86 & 2222.21 \\
\hline TOTAL & 40693.32 & 49960.31 & 69156.00 & 92539.95 & 125453.92 & 177670.89 & 239155.8 & 261116.60 \\
\hline
\end{tabular}




\section{Appendix V. Selected European Countries: Capital, NPL, and Profitability RATIOS, 2007Q3 OR LATEST AVAILABLE}

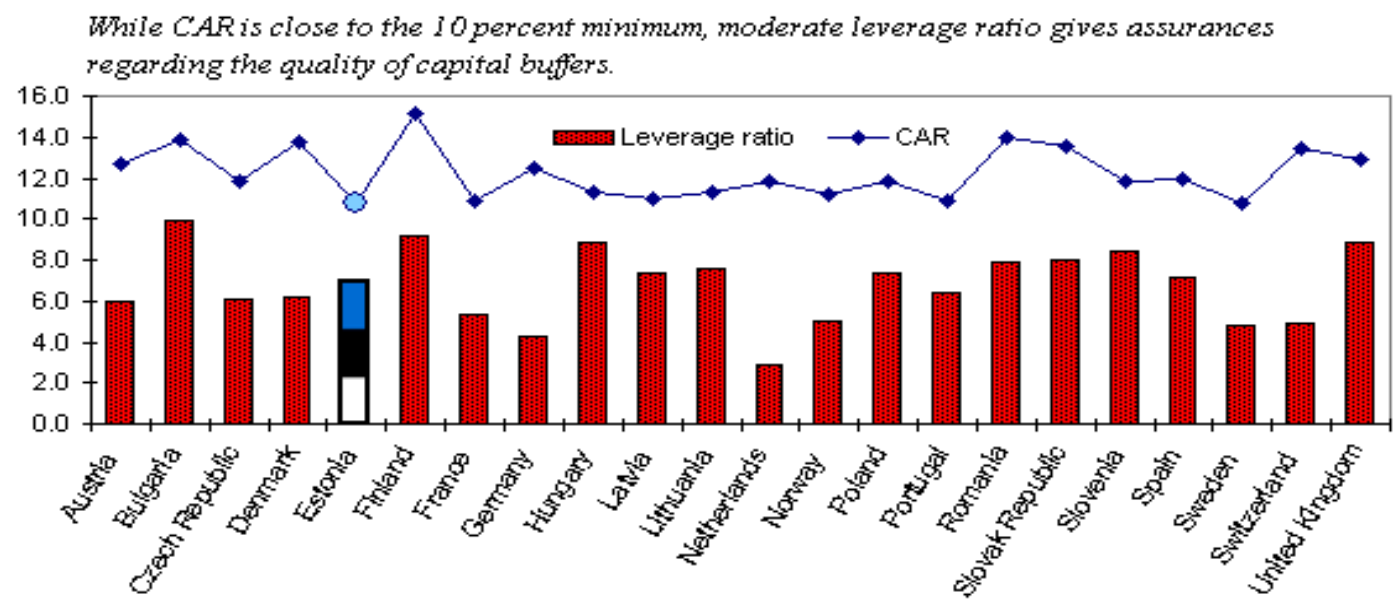

At the same time, conservatively defined NPLs (overdues by 60 days) remain well below

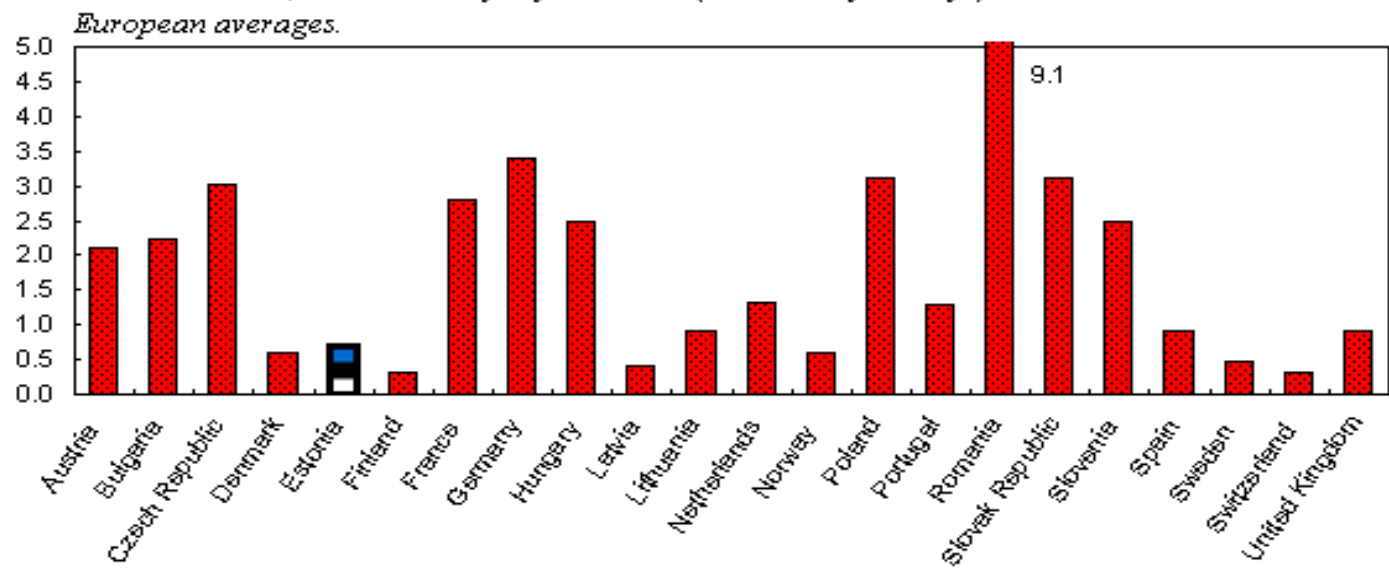

Estonian banking system has also delivered ROA well in excess of the Nordic and EU countries, 3.0
2.5
2.0
1.5
1.0
0.5
0.0 due to its high eficiency.

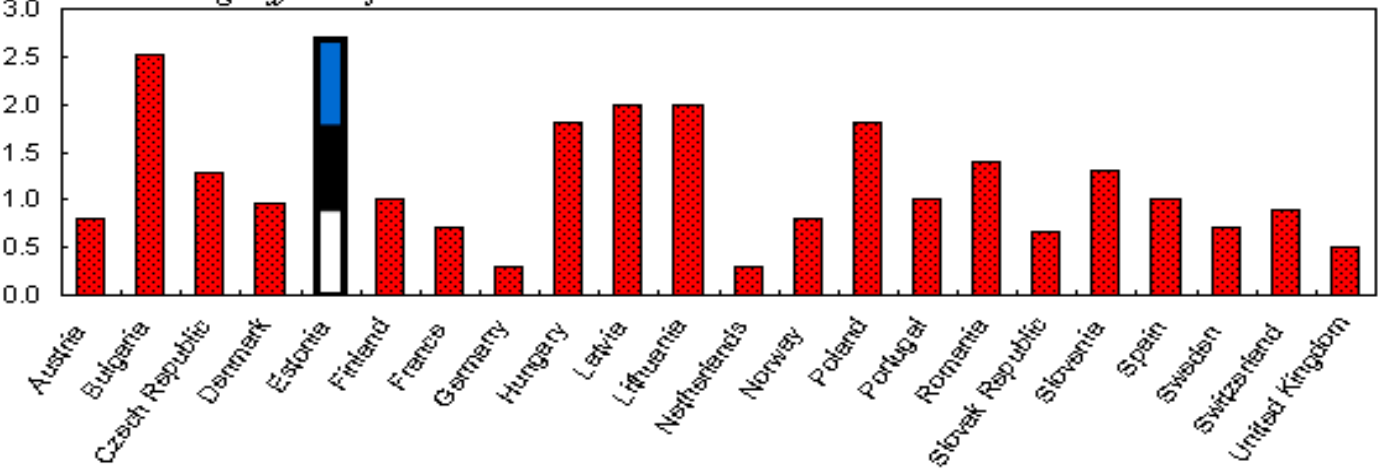

Sources: National authorities; and IMF staff estimates.

Note: Capital adequacy ratios for Estonia are presented on a consolidated bases, incorporating subsidiaries in Latvia and Lithuania. 


\section{ApPendix VI. Estonia: Macroeconomic Stress Test Scenarios: Summary OF Key PARAMETERS}

\begin{tabular}{|c|c|c|c|c|c|c|c|c|c|c|c|c|}
\hline & & & \multirow{2}{*}{\multicolumn{2}{|c|}{ 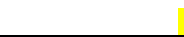 }} & \multirow{2}{*}{\multicolumn{4}{|c|}{ RISK I }} & \multirow{2}{*}{\multicolumn{4}{|c|}{ RISK II }} \\
\hline & & & & & & & & & & & & \\
\hline & 2004 & 2005 & 2006 & 2007 & 2008 & 2009 & 2010 & 2011 & 2008 & 2009 & 2010 & 2011 \\
\hline & & & & Est. & & & & & & & & \\
\hline & & & & & & & & & & & & \\
\hline GDP (constant prices) & $8.3 \%$ & $10.2 \%$ & $11.2 \%$ & $7.3 \%$ & $0.2 \%$ & $6.4 \%$ & $6.2 \%$ & $7.3 \%$ & $-2.5 \%$ & $4.1 \%$ & $3.4 \%$ & $4.0 \%$ \\
\hline Private consumption & $6.7 \%$ & $10.6 \%$ & $15.1 \%$ & $11.4 \%$ & $4.6 \%$ & $3.7 \%$ & $4.5 \%$ & $7.3 \%$ & $3.1 \%$ & $2.5 \%$ & $1.5 \%$ & $1.5 \%$ \\
\hline Investment & $4.4 \%$ & $9.9 \%$ & $22.4 \%$ & $7.5 \%$ & $-13.2 \%$ & $3.1 \%$ & $5.1 \%$ & $11.9 \%$ & $-19.0 \%$ & $-3.4 \%$ & $1.9 \%$ & $5.9 \%$ \\
\hline Exports & $16.6 \%$ & $20.5 \%$ & $8.3 \%$ & $5.2 \%$ & $5.3 \%$ & $7.3 \%$ & $7.2 \%$ & $7.7 \%$ & $3.7 \%$ & $4.3 \%$ & $6.9 \%$ & $8.7 \%$ \\
\hline Imports & $15.5 \%$ & $16.3 \%$ & $17.1 \%$ & $5.0 \%$ & $2.8 \%$ & $3.7 \%$ & $5.6 \%$ & $8.8 \%$ & $0.7 \%$ & $0.4 \%$ & $4.7 \%$ & $7.6 \%$ \\
\hline & & & & & & & & & & & & \\
\hline \multicolumn{13}{|l|}{\begin{tabular}{|l|} 
Monetary/Financial sector \\
\end{tabular}} \\
\hline Money market rate (in percent) & $2.1 \%$ & $2.2 \%$ & $3.1 \%$ & $4.8 \%$ & $4.6 \%$ & $4.5 \%$ & $4.5 \%$ & $4.5 \%$ & $4.6 \%$ & $4.5 \%$ & $4.5 \%$ & $4.5 \%$ \\
\hline Mortgage rate (in percent) & $6.7 \%$ & $4.6 \%$ & $4.2 \%$ & $5.8 \%$ & $6.0 \%$ & $5.9 \%$ & $5.9 \%$ & $5.9 \%$ & $8.0 \%$ & $6.9 \%$ & $6.9 \%$ & $6.9 \%$ \\
\hline \multirow[t]{2}{*}{\begin{tabular}{|l|} 
Credit growth \\
\end{tabular}} & $33.0 \%$ & $50.4 \%$ & $51.6 \%$ & $30.2 \%$ & $9.7 \%$ & $5.5 \%$ & $10.5 \%$ & $11.5 \%$ & $-1.4 \%$ & $-13.8 \%$ & $-6.3 \%$ & $3.1 \%$ \\
\hline & & & & & & & & & & & & \\
\hline \multicolumn{13}{|l|}{ Exchange rate \& prices } \\
\hline CPI inflation (annual average) & $3.0 \%$ & $4.1 \%$ & $4.4 \%$ & $6.2 \%$ & $7.2 \%$ & $4.0 \%$ & $2.7 \%$ & $3.1 \%$ & $7.1 \%$ & $3.4 \%$ & $2.7 \%$ & $3.2 \%$ \\
\hline \multirow[t]{2}{*}{ Residential real estate prices } & $26.6 \%$ & $52.0 \%$ & $31.5 \%$ & $-3.4 \%$ & $-30.0 \%$ & $2.5 \%$ & $4.8 \%$ & $5.3 \%$ & $-0.6 \%$ & $-6.2 \%$ & $-2.8 \%$ & $1.4 \%$ \\
\hline & & & & & & & & & & & & \\
\hline \multicolumn{13}{|l|}{\begin{tabular}{|l|} 
Labor markets \\
\end{tabular}} \\
\hline Employment & $0.2 \%$ & $2.0 \%$ & $6.4 \%$ & $1.3 \%$ & $-1.1 \%$ & $-0.5 \%$ & $-0.1 \%$ & $1.5 \%$ & $-1.7 \%$ & $-1.8 \%$ & $-1.6 \%$ & $0.4 \%$ \\
\hline Gross wages & $7.8 \%$ & $11.4 \%$ & $16.2 \%$ & $20.4 \%$ & $14.3 \%$ & $7.1 \%$ & $6.4 \%$ & $11.1 \%$ & $13.9 \%$ & $4.7 \%$ & $2.8 \%$ & $7.3 \%$ \\
\hline Unemployment (percent) & $9.7 \%$ & $7.9 \%$ & $5.9 \%$ & $5.2 \%$ & $6.6 \%$ & $7.2 \%$ & $7.0 \%$ & $5.9 \%$ & $7.2 \%$ & $8.6 \%$ & $9.3 \%$ & $8.8 \%$ \\
\hline & & & & & & & & & & & & \\
\hline
\end{tabular}

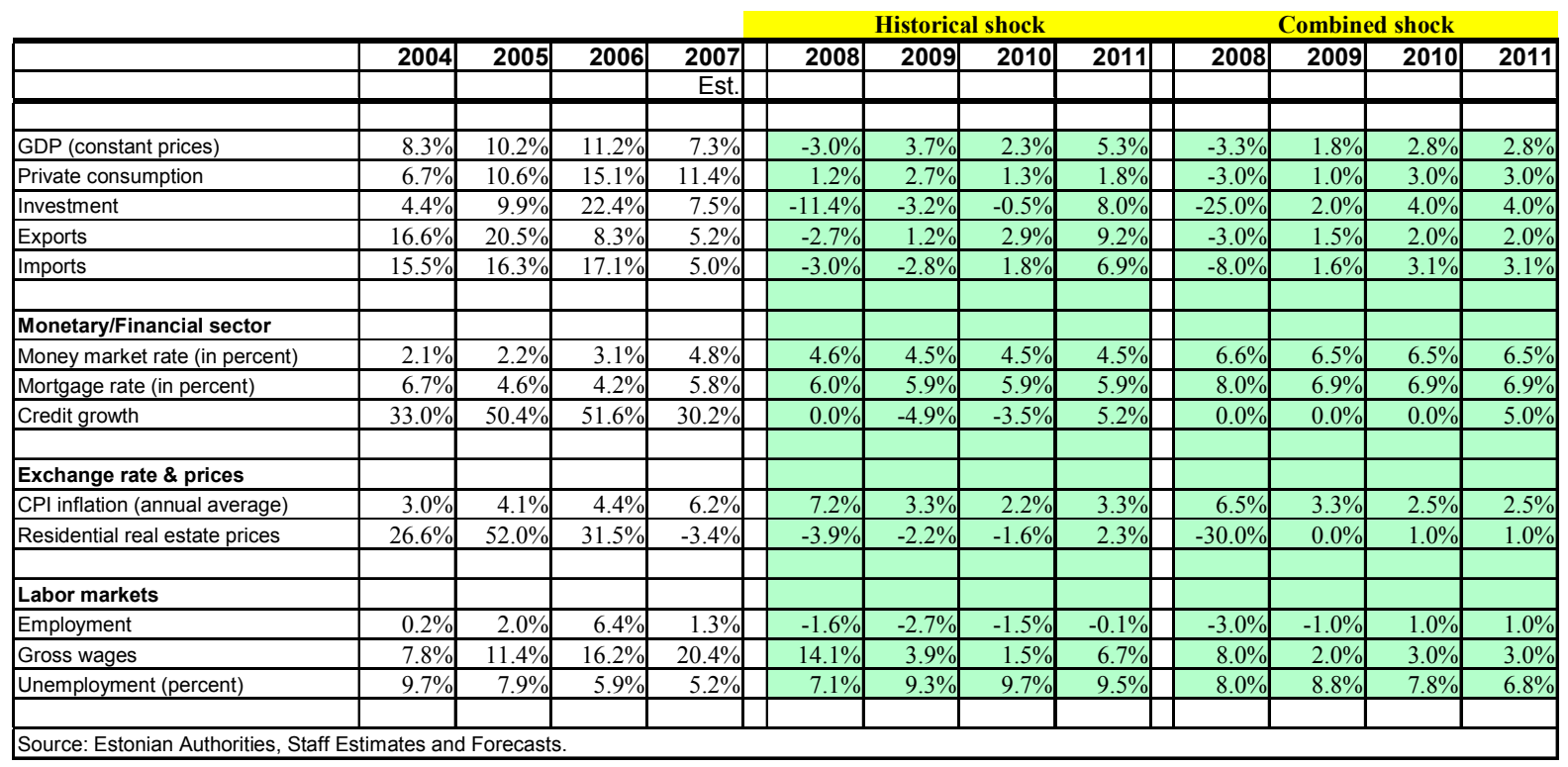

